Özel Hukuk - Araştırma Makalesi

\title{
TÜRK VE RUS HUKUKUNDA ÇOCUĞUN VELÂYETI**
}

\author{
Gulden ABUGALI**
}

\section{GUARDIANSHIP OF CHILDREN IN TURKISH AND RUSSIAN \\ LAW}

\section{Makaleye Atıf}

Klasik Usul: Abugalı, Gulden: Türk ve Rus Hukukunda Çocuğun Velâyeti, Selçuk Üniversitesi Hukuk Fakültesi Dergisi, C. 26, S. 3, 2018, s. 331-392.

APA: ABUGALI, G. (2018). Türk ve Rus Hukukunda Çocuğun Velayeti. Selçuk Üniversitesi Hukuk Fakültesi Dergisi, 26 (3), 331-392. DOI: 10.15337/suhfd.442913.

* Yayın Kuruluna Ulaştığı Tarih: 13.07.2018

Kabul Edildiği Tarih: 28.11.2018

DOI Numarası: $10.15337 /$ suhfd.442913

** Selçuk Üniversitesi Sosyal Bilimler Enstitüsü Yüksek Lisans Öğrencisi

E-mail Adresi: gulden.abugali@mail.ru

ORCID ID: $\underline{\text { 0000-0003-2338-1793 }}$ 


\section{ÖZ}

Sağlıklı toplumun temeli çocuk ve çocuğun aile ile ilişkidir. Çocuğun korunması, yetiştirilmesi ve sağlıklı gelişimi direkt veliye bağlıdır. Anne ve babanın boşanması, anne ve babadan birisi veya ikisinin ölümü, gaiplik, çocuğa yeterli ilgi gösterilmemesi gibi durumlarda, velâyetin kime bırakılacağı söz konusudur.

Bu çalışmada Türk ve Rus hukukundaki çocuğun velâyeti kıyaslanmaya çalışılacaktır. Çocuğun velâyeti ile ilgili kurallar iki hukuk sisteminde benzerlik gösterse de, bir takım farklııklar vardır. Türk ve Rus hukukuna göre velâyetin tanımı, hukuki niteliği, velâyete sahip olanlar ve velâyete tabi olanlar, velâyetin kapsamı ve kullanımı, çocuğun mallarının yönetimi ve kullanımı, velâyetin sona ermesi ve kaldırılma koşulları incelenmeye çalışılmıştır. Çalışmada boşanma sonucunda ortak velâyet, velâyeti anneye bırakılan çocuğa anne soyadı verilmesi gibi güncel konulara değinilmiştir.

ANAHTAR KELIMELER: Türk Hukukunda Çocuğun Velâyeti, Rus Hukukunda Çocuğun Velâyeti, Ortak Velâyet, Velâyetin Kapsamı, Velâyetin Sona Ermesi.

\section{ABSTRACT}

Healthy society is related to the base child and the child's relationship with his/her family. The child's protection, upbringing and healthy development depend directly on the parents. The divorce of the mother and the father, the death of one or both of the parents, the disappearance, the lack of interest in the child are reason of question who will having guardianship.

In this study, it will be tried to compare the children 's rights in Turkish and Russian law. Although the guardianship of children are similar in the two legal systems, there are some differences. According to the Turkish and Russian law, the definition and legal nature of guardianship of children, having guardianship, the children who belong to the guardianship, scope and the usage of guardianship, the management and the use of child's property, and the ending of guardianship and the conditions of lifting the guardianship are examined. As a result of the divorce in the study, common guardianship and giving a mother's surname to a child who has been given a guardianship leave as a divorced mother has been addressed. 
KEY WORDS: Guardianship of Children in Turkısh Law, Guardianship of Children in Russian Law, Joint Child Custody, Scope of Guardianship, Ending of Guardianship.

\section{GiRiş}

Çocuklar belli bir yaşa gelene kadar büyüklere bağlıdırlar ve yardımlarına ihtiyaçları vardır. Çocuğun yetiştirilmesi ve korunması çocuğun doğal haklarındandır. Çocuk doğduğundan itibaren onun bakımı, korunması ve temsil edilmesi velinin görevidir. Çocuk ve veli arasındaki ilişki ve bu ilişkinin sağlıklı yürümesi toplum için her zaman büyük önem arz etmektedir. Çocuk dürüst ve mutlu olarak yetişirse, gelecekte topluma da katkısı olur.

Anne ve babanın boşanması, anne ve babadan birisi veya her ikisinin ölümü, anne ve babanın çocuğa yeterli ilgiyi göstermemesi, gaiplik gibi durumlar ortaya çıkabilir. Böyle durumlarda, çocuğun velâyetinin kime bırakılacağı söz konusudur. Çocuğun velâyeti ile ilgili karar alınırken, öncelik olarak, çocuğun psikolojik ve sosyolojik gelişimi göz önünde tutularak çocuğun menfaati ön planda tutulur. Bu bakımdan velâyet çocuğu korumak için kurulan bir sistem olarak da nitelendirilebilir.

Bu çalışmanın konusu, Türk ve Rus Hukukunda çocuğun velâyetidir. Çalışmanın amacı Türk ve Rus Hukukunda çocuğun velâyeti ile ilgili hükümleri kıyaslamak, eksiklikleri tespit ederek önerilerde bulunmaktır. Bu çalışmada, iki hukuk hukuk sistemine ait kanunlar, aile hukuku ile ilgili kitaplar, araştırma tezleri ve iki ülkenin yüksek mahkeme kararları incelenmiştir.

Türk Hukukunda velâyet direkt anne ve babaya bağlı iken, Rus Hukukunda velâyet sadece anne ve baba değil, akraba veya üçüncü kişilerle de ilgili olabilmektedir. Araştırma altı ana başlıktan oluşmaktadır. Ana başlıklar kendi içinde alt başlıklara bölünmüştür. Çalışma iki hukuk sistemindeki velâyetin tanımı ve hukukî nitelikleri üzerinde değerlendirme yapılmıştır. Türk Hukukunda velâyetin kavramı, Rus Hukukundan çok farkııır, ancak, birçok benzer noktaları da bulunmaktadır.

Velâyete tâbi olanlar ve velâyet hakkına sahip olanlar, üçüncü başlıkta ayrıca incelenmiştir. Türk ve Rus Hukukunda kimler velâyete sahip olabilir ve kimler sahip olamazlar, velâyete tâbi olan çocuklar ve velâyet yaşı da açıklanmıştır. Dördüncü başlıkta Türk ve Rus Hukukuna göre, velâyete ait temel ilkelere yer verilmiştir. 
Beşinci başlıkta iki hukuktaki velâyetin kullanımı ve kapsamı konusu ele alınmıştır. Her ne kadar iki hukukta da velâyetin kullanımı benzerlik gösterse de, velilerin hak ve yetkilerinde farklılıklar vardır. Altıncı başlıkta ise çocuğun korunması ve velâyetin sona ermesine yer verilmiştir. Her iki hukukta da çocuğun korunması, velâyetin sona erme nedenleri ve velâyetin kaldırılması incelenmiştir. Çocuğun yüksek yararına önem veren iki hukukta da, çocuğun bakımı ve yetiştirilmesi için gerekli özen gösterilmediği hâllerde yapılması gereken işlemler izah edilmeye çalışmıştır.

\section{VELÂYETIN TANIMI VE HUKUKI NITELIĞi}

\section{A. VELÂYETIN TANIMI}

\section{Türk Hukukuna Göre Velâyetin Tanımı}

Türk Hukuku'nda Velâyet ile ilgili kurallar 4721 sayılı Türk Medeni Kanunu'nun m.335-363 düzenlenmiştir. Velâyet küçüklerin ve istisnai durumlarda ergin kısıtıların şahıs varlıklarının korunması, bakımı, geliştirilmesi, yetiştirilmesi, mallarına özen gösterilmesi ve korunması, aynı zamanda onların temsil edilmesi konularında kanun koyucunun anne ve babaya verdiği yetki ve haktır ${ }^{1}$. Bu yetki ve hak çocuğun menfaatini ön planda tutarak çocuğun ergin olduğu âna kadar ve istisnai hâllerde ergin

1 Akıntürk, Turgut/ Ateş Karaman, Derya, Aile Hukuku, 6098 Sayılı Yeni Borçlar Kanunu'na Uyarlanmış, C.2, 15.Baskı, İstanbul 2013, s. 406; Kılıçoğlu, Ahmet, Medenî Hukuk, Temel Bilgiler, 3.Bası, Ankara 2013, s. 324; Helvacı, Serap/ Erlüle, Fulya, Medeni Hukuk, 2.Bası, İstanbul 2011, s. 196; Zevkliler, Aydın/ Havutçu, Ayşe, Yeni Medeni Kanuna Göre Medeni Hukuk (Temel Bilgiler), 2.Baskı, Ankara 2002, s.314; Karaca, Hilal, Türk Hukukunda Velâyetin Kapsamı Ve Hükümleri, YL Tezi, İstanbul Ticaret Üniversitesi, İstanbul 2014, s.6., Zeybek, Elvan, Velâyet Hakkının Kullanımı, YL Tezi, Gazi Üniversitesi, Ankara 2009, s.4; Birinci Uzun, Tuba, Türk Medenî Kanunu'na Göre Velâyetin Kullanılması ve Çocuğun Yüksek (Üstün) Yararı İlkesi Doğrultusunda Boşanmada ve Evlilik Dışı İlişkide Birlikte Velâyet Modeli, Hacettepe HFD, 6(1) 2016, 135-166, s.137., Serdar, Illknur, Birlikte Velâyet, DEÜHFD Cilt: 10, Sayı 1, 2008, s. 155-197, s.159; Karakayalı, Gökhan, Velâyet Hakkının Kullanılmasına İlişkin Hukukî Sorunlar Ve Özellikle Koruyucu Aile Uygulaması, YL Tezi, İstanbul Üniversitesi, İstanbul 2009, s.5; Öztürk, Mehmet Atıf, Velâyetin kaldırılması, YL Tezi, Akdeniz Üniversitesi, Antalya 2009, s.3; Zeytin, Zafer/ Ergün, Örner, Türk Medeni Kanunu, 2.Baskı, Ankara 2013, s. 209; Akıntürk, Turgut/ Ateş Karaman, Derya, Medeni Hukuk, 6098 Sayılı Yeni Borçlar Kanunu'na Uyarlanmış, 19.Baskıdan Tıpkı 27.Baskı, İstanbul 2013, s. 301; Ruhi, Ahmet Cemal, Boşanma İle İlgili Mahkeme Illamlarının Türkiye'de Tanınması ve Tenfizi, 1.Basım, Ankara 2003, s.67. 
olduktan sonra da devam edecektir². Velâyet hakkı anne veya babaya, istisnai durumlarda çocuk evlat edinilmiş ise evlat edinene tanınmıştır ${ }^{3}$.

Velâyet hakkı iki yolla kazanılmaktadır. Bunlar: çocuğun doğumu ve mahkeme kararından oluşur. Çocuğun doğumu ve hatta anne rahimine düşmesi ile ortaya çıkan velâyet hakkı, çocuğun evlilik içinde veya evlilik dışında doğmuş olmasına göre kime veya kimlere verileceği konusunda değişiklik göstermektedir ${ }^{4}$.

Evlilik içinde doğan çocuk velâyeti anne ve baba tarafından birlikte kullanımaktadır ${ }^{5}$. Buna karşın, evlilik dışı doğan çocuk velâyeti yalnızca anneye aittir ${ }^{6}$. Daha sonra evlenmeleri durumunda ise çocuk velâyeti anne ve babaya ait olmaktadır. Ortak hayata son verilmiş veya ayrılık hâlinde ise velâyet ikisinden birisine aittır ${ }^{7}$ (TMK m.336). Boşanan anne ve babanın, birbirleri ile tekrar evlenmesi durumunda, boşanma nedeniyle velâyet hakkı sona eren taraf, evlenme ile tekrar velâyet hakkına sahip olacaktır ${ }^{8}$.

Evlilik dışı doğan çocuğun annesinin ergin olmaması durumunda veya farklı sebeplerden dolayı mahkeme kararı ile velâyet babaya verilebilir veya kaldırılabilir. Sonrasında kaldırıma sebepleri ortadan kalkarsa, velâyet tekrar

2 Görgeç, Başak, Türk Medeni Kanunu'nda Velâyet Hükümleri ve Özellikle Çocuğun Korunması, YL Tezi, Marmara Üniversitesi, İstanbul 2011, s.15; Akkurt, Sinan Sami, Çocuğun Kişiliğinin Korunması ve Velâyetin Belirlenmesinde Çocuğun Menfaati Olgusu, Prof. Dr. Rona Serozan'a Armağan, C.1, İstanbul 2010, s. 91-120, s. 93.

3 Serdar, s.159.

4 Hatemi, Hüseyin/ Kalkan Oğuztürk, Burcu, Aile Hukuku, 4.Bası, İstanbul 2004, s. 185; Görgeç, s.17.

5 Görgeç, s.17, Karakayalı, s.5; Serozan, Rona, Çocuk Hukuku, 2.Baskı, İstanbul 2017, s.253; Doğan, İzzet, Öğretide ve Uygulamada Milletlerarası Aile Hukuku ve Milletlerarası Usul Hukuku, 1.Baskı, Ankara 2010, s.579.

6 Serozan, s.253; Helvacı/ Erlüle, s.196; Görgeç, s.17; İsviçre Medeni Kanunu'nu m.298 alınmıştır, (Arpacı, Abdülkadir, Gerekçeleri ve En Son Değişiklikleri ile Yeni Türk Medeni Kanunu, İstanbul 2008, s. 271); Uyumaz, Alper, Türk Medeni Kanununa Göre Çocuğun İhmâli ve Anne Babaya Karşı Korunması, Legal Hukuk Dergisi, C.14, S.160, 2016, s.1973-2005, s.1974.

7 Fakat 6684 sayılı Kanunun yürürlüğe girmesi ile çocuğun menfaatine uygun olması durumunda, boşanan eşler velâyeti birlikte kullanabilirler. Bkz. VI başlık, B/1/c/bb.

8 Görgeç, s.18. 
iade edilir. Evlat edinen kişi, mahkemece verilen evlat edinme kararı ile kendiliğinden velâyet hakkına sahip olacaktır .

\section{Rus Hukukuna Göre Velâyetin Tanımı}

Rus Hukukunda öksüz kalan veya anne ve baba gözetimi dışında kalan çocukları yerleştirmenin dört şekli vardır. Bunlar; velâyet ve vesayet, evlat edinme, aileye yerleştirme, devlet kurumlarına yerleştirmedir ${ }^{10}$. Yerleştirmenin en yaygın şekli velâyet ve vesayettir. Rus Federasyonunda öksüz veya anne ve baba gözetimisiz kalan çocukların \%50si velâyet ve vesayet altındadırlar ${ }^{11}$.

Rus Hukukunda velâyet hükümleri, Rus Medeni Kanunu'nda m.31-40 arası, Rus Aile Kanunu'nda m.145-148.1 arasında ve ayrıca Rus Velâyet ve Vesayet Federal Kanunu'nda da düzenlenmiştir. Rus Hukuku'nda velâyetin tanımı ve hukukî nitelikleri Türk Hukukundan farklıdır. Velâyet; anne ve baba gözetimi dışında kalan on dört yaşını doldurmamış çocukların, yetimlerin ve ehliyetsizlerin yetiştirilmesi, eğitilmesi, mülkiyet hakları ile gayri mülkiyet haklarının ve menfaatlerinin korunmasıdır ${ }^{12}$. Rus Hukukunda velâyet, küçükler ve psikolojik bozukluklar nedeniyle ehliyetsizlere karşı kullanılmaktadır (RMK m.32/1). Ön dört yaşını doldurmamış çocuklar ve ehliyetsizlerin tüm hak ve görevleri velâyeti kendisine bırakılan kişi tarafından gerçekleşmektedir ${ }^{13}$. Velâyetin asıl amacı anne ve baba gözetiminden mahrum kalan çocuğa ailede yaşama ve yetişme imkânı

9 Görgeç, s.19.

10 Кузнецова Е.М., Организация Опеки и Попичительства Над Несовершеннолетними На Муниципальном Уровне, УДК 352, 364, г.Омск 2010, s.140.

11 Кузнецова, s.58.

12 Мартынова Е.В., Опека и Попичетелство, Учебное Пособие, г.Ростов На Дону 2014, s.6; Сумбаa Ш.А., Опека и попечительство как форма социальной защиты детей, оставшихся без попечения родителей, Выпускная Квалификационная Работа, Кызылский Педагогический Институт, Кызыл 2015, s.18; Пулатов Т.А., Правовое регулирование опеки и попечительства в Российской Федерации, Магистерская Диссертация, Тольяттинский государственный университет, г.Тольятти 2017. https://dspace.tltsu.ru/handle/123456789/3239 (Erişim tarihi: 5.01.2018), s.7; Рузакова, О.А., Семейное Право, Учебник, г.Москва 2010, s.147;

Войтович Е.П., Семейное Право, Учебное Пособие, Новосибирск 2014, s.134135; Крашеников, П.В., Семейное Право, Учебник, г.Москва 2008. s.116.

13 Сумбаa, s.18; Пулатов, s.8. 
sağlamaktır. Velâyetten doğan görevler söz konusu kanunda açıkça düzenlenmedikçe maddî karşılığı yoktur ${ }^{14}$.

Rus Hukukunda velâyet ve vesayet birbiri ile benzerlik göstermektedir, ancak, bazı farklılıklar da mevcuttur. Velâyette veli, velâyet altındaki küçüğün adına tüm hukukî işlemleri gerçekleştirebilir. Vesayette ise, vasi çocuğun sadece bir yardımcısıdır ve işlemlerde çocuğa yalnızca tavsiye verebilir veya izin vermemekle çocuğu koruyabilir. Yukarıda bahsedildiği gibi velâyet, on dört yaşını doldurmamış çocuklar için geçerlidir. Vesayet ise on dört yaşından on sekiz yaşına kadar çocuklar için söz konusudur ${ }^{15}$.

Anne ve baba gözetiminden mahrum kalan çocuğa bir ay içinde veli atanmazsa, velâyet atanana kadarki sürede Velâyet ve Vesayet Kurumu ${ }^{16}$ çocuğun bakımını üstlenecektir ${ }^{17}$. Velâyet belirlenirken çocuğun görüşü alınması gerekir. On yaşını doldurmuş çocuk velâyetle ilgili mahkemede kendi görüşünü bildirebilir ve velâyeti onun rızası ile belirlenir ${ }^{18}$. Velâyete sahip olan kişi velâyet altındakilerin mallarını yönetir, onların adına ve onların menfaatine göre hukukî işlemler yapar, kanunun verdiği yetki ile hâkimin iznini almadan üçüncü kişilere karşı ve mahkemede çocuğu temsil eder ${ }^{19}$.

14 Сумбаa, s.20.

15 Максимов И.Н., Опека и Попичителство Как Вид Социальной Заботы Государства, Издание Наука Вестник, г.Шадринск 2013, s.3; Сумбаa, s.18.

16 Velâyetle ilgili işlemleri: velâyeti belirleme, kaldırma, takip etme vb. kararları Velâyet ve Vesayet Kurumu gerçekleştirir. Velâyet ve Vesayet Kurumu bölgesel yönetme ve yerleştirme devlet kurumlarıdır. Velâyet ve Vesayet Kurumu erginliğe erişmemiş çocuklar, engelliler, tam ve sınırlı ehliyetsizler ile ilgili işlemleri yapar. Velâyet ve Vesayet Kurumunun en önemli görevleri; anne ve babadan uzak kalan çocukları tespit etmek, onları yerleştirmek, maddî ve manevi yardım etmek, çocuklara veli atamak, onları korumak. (Войтович, s.135-137).

17 Попова Т.А., Проблемы Правового Регулирования Отношений, Связанных С Установлением Над Несовершеннолетним (Опеки и Попечительства), Выпускная Квалификационная Работа, Томский Государственный Университет, г.Томск 2016, s.44-45.

18 Гомола А.И. / Гомола И.А., Семейное право, Учебник, Москва 2014, s.134.

19 Сумбаa, s.18. 


\section{B. VELÂYETIN HUKUKî NITELIĞi}

\section{Türk Hukukuna Göre Velâyetin Hukukî Niteliği}

Öğretide, bir görüşe göre velâyet, başkaları üzerinde mutlak hak olarak sınıflandırılmaktadır ve anne baba velâyet hakkını bu hakkı ihlâl eden herkese karşı ileri sürebilmektedir ${ }^{20}$. Bu görüşe göre, şahıslar hakkın konusu olamazlar, fakat kendini koruyamayan ve aciz kişiler istisnaî olarak değerlendirilmiş ve bu şahıslar üzerinde mutlak hakkın olduğu kabul edilmiştir ${ }^{21}$. Bu görüş sahipleri, velâyetin anne ve babanın yararından ziyade, çocuk yararına tanınan ve çocuğu korumayı amaçlayan bir hak olduğunu ileri sürmektedir ${ }^{22}$.

Diğer bir görüşe göre, velâyet, anne ve babaya yalnızca haklar tanımaz, hakla birlikte bazı yükümlülükler de yükle ${ }^{23}$. Bu görüşe göre, anne ve babaya, çocuğun kişisel gelişimi ve malvarlığına ilişkin birtakım görevler yüklenmiştir ${ }^{24}$. Buna neden olan, velâyetin kaldırılması durumunda anne ve babanın görevinin devam etmesidir. Mesela; boşanmada çocuk velâyeti kendisinde olmayan tarafın çocuğa karşı nafaka yükümlülüğünün devam etmesi gibi ${ }^{25}$. Bunun yanı sıra anne veya babanın, velâyetin kullanılması esnasında çocuğa bir vasi tayini isteyerek velâyetten kurtulamayacağı veya velâyetin başka birisine devir edilemeyeceği öne sürülmektedir ${ }^{26}$. Fakat, anne ve baba, kendilerini yetersiz görükleri durumda, velâyetin kaldırılması veya değiştirilmesi konusunda hâkime başvurabilirler. Bu durumda hâkim gerekli araştırmaları yaparak, velâyetin kaldırılması veya diğer önlemlerin

20 Bozkurt, İkbal, Velinin Velâyetten Doğan Hak Görev Ve Yetkileri, YL Tezi, İstanbul Üniversitesi, İstanbul 2010 https://tez.yok.gov.tr/UlusalTezMerkezi/ (Erişim tarihi: 7.09.18), s.16.

21 Karaca, s.8; Uyumaz, Alper, Türk Medeni Kanununa Göre Çocuğun İhmâli ve Anne Babaya Karşı Korunması, Legal Hukuk Dergisi, C.14, S.160, 2016, s.1973-2005 (Uyumaz, Çocuğun Korunması), s.1973.

22 Karaca, s.8; Bozkurt, s.16

23 Zevkliler/ Havutçu, s. 314; Akıntürk/ Ateş Karaman, Aile, s. 407; Zeybek, s.5, Görgeç, s.5; Zeytin/ Ergün, s. 209; Akıncı, Ziya/ Demir Gökyayla, Cemile, Milletlerarası Aile Hukuku, İstanbul 2010, s. 146; Akyüz, Emine, Çocuk Hukuku, Çocukların Hakları ve Korunması, 5.Baskı, Ankara 2016, s.224.

24 Akyüz, s.223.

25 Zeybek, s.5.

26 Zeybek, s.5. 
alınması için karar verebilir ${ }^{27}$. Bu nedenle, velâyetin bir hak olduğu görüşü daha tutarlıdır.

\section{Rus Hukukuna Göre Velâyetin Hukukî Niteliği}

RVVFK m.11/2'ye göre velâyet belirlenirken veli olacak kişinin rızası şarttır. Kendi isteği ile veli olmak isteyen şahısların ise Velâyet ve Vesayet kurumuna dilekçe ile başvurmaları gerekemektedir. RVVFK m.5'de velâyetin ilkeleri düzenlemiştir. Bu maddeye göre, veli velâyeti kendi isteği ile üstlenir ve kendi isteği ile velâyetten vazgeçebilir. Veli kendi isteği ile velâyetten doğan hak ve görevlerinden vazgeçtiği durumda, velâyet sona erecektir. Bu nedenle velâyetten vazgeçmek velinin hakkıdır ${ }^{28}$. Görüldüğü üzere, Rus hukukuna göre velâyet tartışmasız bir haktır.

\section{VELÂYET HAKKINA SAHIP OLANLAR VE VELÂYETE TÂBI OLANLAR}

\section{A. VELÂYET HAKKINA SAHIP OLANLAR}

\section{Türk Hukukuna Göre Velâyet Hakkına Sahip Olanlar}

Türk Hukukunda velâyet hakkı, sadece anne ve babaya aittır ${ }^{29}$. TMK m.335/1 uyarınca, yasal sebep olmadıkça velâyet anne ve babadan alınamaz. Evlat edinen de ergin olmayan evlatlık üzerinde velâyet hakkında sahiptir ${ }^{30}$ Anne ve baba evliyse çocuk dünyaya geldiği anda velâyet kanundan doğar ${ }^{31}$. TMK m.337'ye göre, anne ve baba evli değilse velâyet anneye aittir. Çocuğun menfaati açısından küçüğün anne yanında kalmasının onun için daha iyi olduğu kabul edilmektedir ${ }^{32}$. Anne erginliğe ermemiş, kısıtlı veya ölmüş ya da velâyet kendisinden alınmışsa çocuğun menfaatine göre çocuğa vasi atanır

\section{$27 \quad$ Karaca, S.8}

28 Войтович, s.142; Рузакова, s.149; Попова, s.61.

29 Gökçe, Ümit, Medeni Hukuk, Prestij Kitapları III, Ankara 2004, s. 61; Akıntürk/ Ateş Karaman, Aile. S.407, Hatemi/ Kalkan Oğuztürk, s. 185; Akıncı/ Demir Gökyayla, s. 146; Helvacı/ Erlüle, s. 196; Akıntürk/ Ateş Karaman, Medeni, s. 301.

30 Akıntürk/ Ateş Karaman, Aile. S.407.

31 Akıncı/ Demir Gökyayla, s. 146; Hatemi/ Kalkan Oğuztürk, s. 185.

32 Y. 2.HD, 24.02.2003, E.2003/1375, K.2003/2372: “Anne yanında kalmasının çocuğun bedeni, fikri, ahlâki elişmesine engel olacağı yönünde ciddi ve inandırıcı deliller bulunmadığı ve hemen meydana gelecek tehlikelerin varlığı da ispat edilmediği halde anne bakım, şefkatine muhtaç ...... TMK m.182, 336/2 uayrınca, babanın velyetine bırakılması usul ve kanuna aykırıdır" (http://www.kazanci.com.tr/) Erişim tarihi 05.06.2018, Akkurt, Makele, s. 114. 
veya velâyet babaya verilir ${ }^{33}$. Evlat edinmede, evlat edinen tarafından evlat edinme işlemleri tamamlanıp, hâkimin kararının kesinleşmesi ile velâyet kazanılır ${ }^{34}$.

Evlilik devam ettiği sürece anne ve baba velâyeti birlikte kullanırlar ${ }^{35}$. Anne ve babadan birinin ölümü hâlinde ise velâyet sağ kalana ait olacaktır ${ }^{36}$. Anne baba ve evlat edinenler haricinde üçüncü kişiler, yakın hısım dahi olsalar velâyet hakkına sahip olamazlar ${ }^{37}$. Büyük anne ve büyük baba ${ }^{38}$, üvey anne veya üvey babanın velâyet hakkı yoktur. Üçüncü kişiler sadece vasi olabilirler ${ }^{39}$. Ancak, TMK m.338 gereğince, üvey anne ve üvey baba velâyete sahip olan eşlerine yardım etmekle ve ergin olmayan üvey çocuklarına özen ve ilgi göstermekle yükümlüdürler ${ }^{40}$.

\section{Rus Hukukuna Göre Velâyet Hakkına Sahip Olanlar}

Rus Hukukunda erginliğe erişmiş, fiili ehliyeti olan herhangi bir kişi velâyete sahip olabilir ${ }^{41}$. Velâyetle ilgili işlemleri Velâyet ve Vesayet Kurumu gerçekleştirir ve takip eder ${ }^{42}$.

33 Serozan, s.254; Bu madde, İsviçre Medeni Kanunu m.298'den alınmıştır. (Arpacı, s. 371); Doğan, s.579.

34 Akıntürk/ Ateş Karaman, Aile. S.407.

35 Kılıçoğlu, Medenî, s. 324; Zeytin/ Ergün, s. 210, Tutumlu, Mehmet Akif, Teorik ve Pratik Boşanma Yargılama Hukuku, C.2, 2.Baskı, Ankara 2009, s. 1351; Akıncı/ Demir Gökyayla, s. 146; Helvacı/ Erlüle, s. 196.

36 Zeytin/ Ergün, s. 210; Helvacı/ Erlüle, s. 196; Hatemi/ Kalkan Oğuztürk, s. 185; Öztürkmen İcan, Yeşim, Hâkimin Takdir Yetkisinin Velâyete İlişkin Yargıtay Karar Örnekleri Üzerinde Değerlendirilmesi, YL Tezi, Ondokuz Mayıs Üniversitesi, Samsun 2015 https://tez.yok.gov.tr/UlusalTezMerkezi/ (Erişim tarihi: 7.09.18), s.69.

37 Akıntürk/ Ateş Karaman, Aile, s.407, Hatemi/ Kalkan Oğuztürk, s. 185; Gökçe, s.61; Akıntürk/ Ateş Karaman, Medeni, s. 301; Serozan, s.254.

Y. 2.HD, 08.06.2008, E.2008/3782, K.2008/8892: “...yasal düzenlemelere göre, velâyet hakkı, münhasıran anne ve babaya tanınan bir hak olup, evlat edinme hâli hariç, anne ve baba dışında hiç kimseye tevdi olunamayacağından, mahkemece velâyetin küçüklerin dedesi olan davacıya verilmesi şeklinde hüküm kurulması usul ve yasaya aykırıdır" (Tutumlu, s.1369.)

39 Akıncı/ Demir Gökyayla, s. 146; Serozan, s.254.

40 Serozan, s.254; Hatemi/ Kalkan Oğuztürk, s. 185.

41 Сумбаa, s.19; Попова, s.27; Рузакова, s.147; Войтович, s.138.

42 Войтович, s.135. 
RAK m.146/l göre, aşağıdaki kişilere velâyet verilemez:

- Daha önce velâyet hakkı kaldırılmış kişilere: söz konusu hak ne zaman kaldırımış olmasına bakılmaksızın velâyet hakkı verilmemektedir ${ }^{43}$.

- İnsan hayatına ve sağlığına, kişinin ar namusuna, insanlığa, barışa, aileye, küçüklere ve cinsel özgürlüğe karşı suçlardan dolayı sabıka kaydı olanlar ${ }^{44}$.

- Ağır ceza suçlarından sabıka kaydı silinmeyenler ${ }^{45}$.

- Ön hazırlıktan ${ }^{46}$ geçmeyen kişiler, çocuğun yakın hısımları, daha önce evlat edinmiş ve evlatlık hakkı kaldırılmamış, daha önce velâyete sahip olan ve görevini gereği gibi yerine getirmemesinden dolayı velâyeti kaldırılmamış kişiler istisnadır ${ }^{47}$.

- Eşcinsel evliliği olanlar ve eşcinsel ailelerin evliliklerini kanunlaştıran bir ülkede evliliklerini resmileştirenler, eşcinsel ailelerin evliliklerini kanunlaştıran ülkenin bekâr vatandaşları ${ }^{48}$.

43 Войтович, s.138; Низамиева О.Н., Семейное Право, учебно-методический комплекс дисциплины, Казанский (Приволжский) федеральный университет, Казань 2014s, 103; Рузакова, s.147; Сумбаa, s.19; Попова, s.27; Гомола А.И./ Гомола И.А., s.133.

44 Войтович, s.139.

45 Daha önce iki kez ceza almış, ancak, sabıka kaydı silinen kişiler veli olabilirler. Ceza almış olması çocuğa terbiye vermekte yan etkisi bulunmamaktadır ve velâyeti kaldırmaya sebep değildir. Решение BC № 33а-15216/2017 A-019a 11.12.2017 (Решение ВC РФ: https://rospravosudie.com/court-krasnoyarskij-kraevoj-sudkrasnoyarskij-kraj-s/act-561047667/) Erişim tarihi: 1.03.2018.

46 RAK m.127/6'ya göre, kişi velâyete sahip olabilmesi için psikolojik pedagojik ve hukukî taraftan hazır olmalıdır. Velâyete sahip olmak isteyen kişinin öz hazırlık eğitimini aldığı sertifikası bulunması zorunludur. Ön hazırlık sertifikası Velâyet ve Vesayet Kurumu tarafından organize edilen eğitimden sonra verilecektir. Yabancı uyruklu ve yurtdışında ikamet eden kişiler RF vatandaşı olan çocuğun velâyetini almak için, RF yasalarına uygun ön hazırlık sertifikasını almışsa RF'da geçerlidir, almamışsa RF sınırları için öz hazırlıktan geçmesi zorunludur; Войтович, s.139.

Попова, s.27.

48 Войтович, s.139; RF devleti eşcinsel evlilikleri kabul etmiyor ve dolayısıyla eşcinsel evliliklerini başka ülkede resmileştiren kişiler RF'da velâyete sahip olamazlar. Fakat eşcinsel evliliği kabul eden ülke vatandaşlarının normal evliliği (kadın ve erkek evliliği) mevcut ise, RF'da velâyete sahip olabilirler. Eşcinsel evliliği kabul eden ülkenin henüz bir evlilik yapmamış olan bekâr vatandaşlarının $\mathrm{RF}^{\prime}$ da velâyete sahip 
- Kronik alkol ve uyuşturucu madde bağımlıları ${ }^{49}$.

- Kanunda belirtilen özelliğe sahip olanlar velâyete sahip olamazlar. Velâyet atanırken hâkim veli olacak kişinin ruhanî ve fiziksel özelliklerini de dikkate alır.

Psikolojik hastalar ve velâyet görevini yerine getirmeye engel bedensel hastalıkları olanlar da velâyete sahip olamazlar ${ }^{50}$. Velâyetle ilgili karar aşamasında hâkim, hastanenin psikiyatr bölümü kayıtlarından kişi hakkında bilgi edinebilir ve kendi takdir yetkisine göre karar verebilir ${ }^{51}$.

\section{B. VELÂYETE TÂBI OLANLAR}

\section{Türk Hukukuna Göre Velâyete Tâbi Olanlar}

TMK m.335'e göre, ergin olmayan çocuklar, yani on sekiz yaşından küçük çocuklar velâyete tâbidirler ${ }^{52}$. Kural olarak erginliğe ulaşan çocuklar velâyete tâbi olamazlar ${ }^{53}$. Erginliğe kavuşmayan küçükler, evlenme ve bunun gibi başka istisnai durumlarda on sekiz yaşını doldurmamış olsalar bile velâyet altında değildirler ${ }^{54}$. Zira evlenme kişiyi reşit kılar (TMK m.11). Evlatlıkta da çocuklar erginliğe ulaşana kadar evlat edinenin velâyetindedirler ${ }^{55}$. Evlat edinen ölürse, velâyet kendiliğinden doğal anne ve babasına geçmez, çocuğa vasi atanır. Ancak, çocuğun doğal anne ve babası da vasi olarak atanabilir ${ }^{56}$. Mahkeme kararı ile ergin olmuş fakat kısıtlanmış

olamama sebebi ise, daha sonra kendi ülkelerinde eşcinsel evlilik yapabilme ihtimali olduğundandır. Yani kanun koyucu çocuğun sadece maddi değil manevi açıdan da sağlıklı ailede büyümesi için böyle bir kural oluşturmuştur (Семейный кодекс РФ 2018, Актуальная редакция с Комментариями по состоянию на 17.09.2018 http://skodeksrf.ru/rzd-6/gl-19/st-127-sk-rf) Erişim tarihi: 12.10.2018.

49 Рузакова, s.147; Попова, s.27; Низамиева, s.103; Войтович, s.139; Гомола А.И./ Гомола И.А., s.133.

50 Гомола А.И./ Гомола И.А., s.133; Попова, s.28-29.

51 Попова, s.28-29.

52 Helvacı/ Erlüle, s. 196; Zevkliler/ Havutçu, s. 315; Zeytin/ Ergün, s. 210; Akıntürk/ Ateş Karaman, Aile. S.408.

53 Akıntürk/ Ateş Karaman, Aile, s.408; Zevkliler/ Havutçu, s. 315.

54 Zevkliler/ Havutçu, s. 315.

55 Zevkliler/ Havutçu, s. 315.

56 Arat, Ayşe, Medenî Kanun'da Velâyetin Kaldırılması Tedbiri ve Bu Tedbirin Uygulanması, MÜHFD, C.2, S.2, Aralık 2012, 275-296, s.277. 
çocuğa vasi atanmasını gerek görülmediği durumlarda da ergin çocuklar, anne ve babanın velâyeti altında kalırlar ${ }^{57}$.

\section{Rus Hukukuna Göre Velâyete Tâbi Olanlar}

RMK m.31'e göre, anne ve babası veya evlat edineni olmayanlar, anne ve babasından velâyet kaldırılmış ve anne ve baba gözetimi dışında kalan erginliğe erişmemiş çocuklar da velâyete tâbidirler ${ }^{58}$. On dört yaşını doldurmayan çocuklar velâyete tâbi olup, on dört yaşından on sekiz yaşına kadar olan çocuklar ise velâyete değil, vesayete tâbi olmaktadırlar ${ }^{59}$. RMK m.35/4'e göre, çocuk esirgeme kurumlarına, eğitim ve sağlık kurumlarına, sosyal yardımlar yapılan kurumlara yerleştirilmiş tam ehliyetsiz veya sınırlı ehliyetsizler velâyete tâbi olamazlar.

\section{VELÂYETE HÂKIM OLAN ILLKELER}

\section{A. TÜRK HUKUKUNA GÖRE VELÂYETE HÂKIM OLAN ILLKELER}

\section{1. Çocuğun Menfaati İlkesi}

Velâyetin asıl işlevi çocuğun menfaatinin korunmasıdır ${ }^{60}$. Çocuğun menfaati kavramı Türk Medeni Kanununda veya Birleşmiş Milletler Çocuk Haklarına Dair Sözleşmede de açıkça tanımlanmamıştır, fakat hem öğretide ${ }^{61}$ hem uygulamada ${ }^{62}$ çocuğun menfaatinin ön planda tutulması amaçlanmıştır. Anne ve babanın ortak hayata son vermesi veya ayrılık hâlinde, velâyet hakkı anne ve babadan birisine ya da her ikisine bırakılır63. Velâyetin hangi tarafa bırakılacağı konusunda hâkime geniş takdir yetkisi verilmiştir. Hâkim

57 Serozan, s.251; Akıntürk/ Ateş Karaman, Medeni, s.301; Helvacı/ Erlüle, s. 196; Zevkliler/ Havutçu, s. 315; Arpacı, s. 370; Zeytin/ Ergün, s. 210; Akıntürk/ Ateş Karaman, Aile, s..408.

58 Низамиева, s.102.

59 Низамиева, S.102.

60 Görgeç, s.20; Partalcı, Rumeysa, Yabancı Devletlerden Alınan Velâyet Kararlarının Tenfizi, YL Tezi, İstanbul Üniversitesi, İstanbul 2014 https://tez.yok.gov.tr/UlusalTezMerkezi/ (Erişim tarihi: 7.09.18), s.56.

61 BMÇHDS m.3: "Kamusal ya da özel sosyal yardım kuruluşları, mahkemeler, idari makamlar veya yasama organları tarafından yapılan ve çocukları ilgilendiren bütün faaliyetlerde, çocuğun yararı temel düşüncedir".

62 Y. 2.HD, 22.11.2001, E.2001/14060, K.2001/16341: “...Velâyetin düzenlenmesinde asıl olan küçüğün yararı olup bu hususun kamu düzeni gereğince davaya bakan hâkim tarafından kendiliğinden gözetilmesi gerekir. ..." (Ruhi, s.69).

63 Akyüz, s.233. 
velâyetin hangi tarafa bırakılacağına karar verirken çocuğun menfaatini gözetmesi gerekir. Çocuğun menfaati tespitinde kullanılacak ölçütler, her ne kadar kanunda açıkça belirtilmiş olmasa da, olayın özelliklerine göre ayrı ayrı takdir edilmelidir ${ }^{64}$.

Doktrinde "The Tender Years Doctrine" adında bir görüş, çocuğun menfaatini tespit etme konusunda çocuğun yaşını nazara almaktadır. Bu görüş, çocuğun menfaati doğrultusunda, belirli yaşın altındaki çocukların velâyetini anneye verilmesi gerektiğini savunmaktadır. "The Tender Years Doctrine" görüşüne göre, "hassas yaşlar" olarak adlandırılan dönemdeki çocukların refahı ve mutluluğu, ancak anneye verilmesi ile sağlanabilir. Yani, velâyetin anneye verilmesinde, annenin sosyal ve ekonomik durumu önem arz atmemektedir. Türk Hukuk doktrininde ise, velâyetin anne ve babadan hangisine verileceğine karar verilirken, çocuğun menfaatininin göz önünde bulundurulması gerekmektedir ${ }^{65}$.

Velâyet ilişkisi çift taraflıdır ${ }^{66}$. Yukarıda da bahsettiğimiz gibi velâyet anne ve babaya çocuğun şahsı ve malları üzerine sadece haklar değil, aynı zamanda onlara birtakım yükümlülükler de yükler. Genelde anne ve baba ve çocuğun menfaatleri aynı yöndedir. Ancak, anne ve baba ve çocuğun çıkarları çatıştığı durumlarda kanun bu hakkın kullanılmasında çocuğun menfaatini ön planda tutmuştur ${ }^{67}$. TMK m.339'da çocuğun bakımı ve eğitimi konusunda onun menfaatini göz önünde bulundurarak gerekli kararları almaları ve uygulamaları gerektiği belirtilmiştir.

Çocuğun menfaati ilkesi gereği, çocuğun bedensel, zihinsel, ruhsal, ahlâki ve toplumsal taraftan gelişimi için gerekli tüm şartlar sağlanmalıdır68. Çocuğun menfaati, genel olarak kendi ayaklarında durabilme, sorumluluk alabilme, toplum içinde sorun yaşamadan hayatını sürdürebilir hâle gelmesi için doğru yetiştirilmesi şeklinde tanımlanabilir69. Mesela; çocuk ergin olduktan sonra kendi başına karar verebilmesi için, büyüme aşamasında

\footnotetext{
64 Akkurt, Makale, s. 115.

65 Akkurt, Makale, s. 114.

66 Akıntürk/ Ateş Karaman, Aile, s.407; Zeybek, s.6; Karakayalı, s.19; Öztürk, s.6.

67 Karakayalı, s.19; Öztürk, s.6; Öztekin Gelgel, Günseli, Devletler Özel Hukukunda Velâyet, Çocuk Kaçırmaları, Evlat Edinmeye İlişkin Problemler, İstanbul Ticaret Üniversitesi Sosyal Bilimler Dergisi Yıl:4 S.8 Güz 2005/2 s.119-148, s.128.
}

68 Akkurt, Makale, s.111; Serdar, s.163.

69 Görgeç, s.20. 
kendisi ile ilgili bazı kararlara katılması gerekmektedir. Ergin olana kadar fikri sorulmamış çocuk, ergin olduktan sonra karar alma konusunda yetersiz kalacaktır. Görüldüğg̈ üzere bu çocuğun menfaatine aykırı bir durumdur ${ }^{70}$. Velâyet hakkının kullanımına ilişkin kararlarında, Yargıtay, öncelikle çocuğun çıkarlarının ön plana koyulması gerektiğini, daha sonra anne ve baba durumuna bakılması gerektiğini belirtmişsir ${ }^{71}$.

\section{Süreli Olma İlkesi}

Velâyet ilişkisi sürelidir ${ }^{72}$. Yukarıda bahsettiğimiz gibi, velâyet ilişkisi kural olarak çocuğun doğumu ve hatta anne rahmine düşme anı ile başlar. Velâyet ilişkisi çocuğun büyümesi ile daralır ve ergin olmasıyla son bulur ${ }^{73}$. BMÇHDS m.1'e uyarınca velâyet süresi çocuğun on sekiz yaşına kadar devam edecektir ${ }^{74}$. Ancak, mahkeme kararı ile on sekiz yaşını doldurmayan çocuk ergin kılınırsa veya evlenirse velâyet sona erecektir ${ }^{75}$. TMK m.419/2'e göre, gerek duyulduğunda ergin çocuk mahkeme kararı ile kısılanabilir, ancak, kısıtlama kararı ergin olduktan sonra sonuç doğurur. Böyle durumlarda velâyet devam edilecektir ${ }^{76}$. Gördüğümüz üzere, velâyet ilişkisi anne ve babanın isteği ile sona eremez ve sona ermesi için anne ve babanın izni de aranmaz.

\section{Bölünmezlik İlkesi}

Evlilik devam ettiği ve tarafların birinden alınmadığı sürece velâyetin verdiği yetki ve yükümlülükler anne ve baba arasında bölünmez ve

70 Görgeç, s.21.

71 Y. 2.HD, 20.09.2004, E.2004/9116, K.2004/10227: “... Velâyet düzenlenirken analık, babalık duygularından önce çocuğun geleceği, ihtiyaçları, bedeni ve fikri gelişimi öncelikle dikkate alınır" (Karakayalı s.19); Y. 2.HD, 02.03.2001, E.2001/1902, K.2001/3529: "Ortak çocuk annemin yanında daha rahatım, annemin yanında kalmak istiyorum" demiş.... Velâyetin düzenlenmesinde çocuğun ruhsal yönden rahat olacağı ortamı esas alınır... Velâyetin düzenlenmesinde çocuğun bu arzusunun dikkate alınması gerekir" " (http://www.kazanci.com.tr/) Erişim tarihi 05.06.2018.

72 Serozan, s.251; Zeybek, s.8; Bozkurt, s. 29.

73 Serozan, s.251; Zeybek s.6; Bozkurt, s.29; Görgeç, s.22.

74 Karakayalı, s.24; Görgeç, s.22; Bozkurt, s.29.

75 Bozkurt, s.29; Görgeç, s.22; Karakayalı, s.24.

76 Görgeç, s.22; Zeybek, s.6; Bozkurt, s.29; Serozan, s.251. 
paylaşılamaz ${ }^{77}$. Anne ve baba velâyetin verdiği tüm yetki ve yükümlülükleri birlikte yerine getirmeleri gerekmektedir. Mesela; anne çocuğun bakımını yapacak, baba da eğitimine bakacak şeklinde paylaşılamamaktadır.

Çocuğun menfaatine ve mallarına özen gösterilmesini amaçlayan hak ve yükümlülükler bölünmediği gibi zaman bakımından da velâyet bölünmez ${ }^{78}$. Çocuğun menfaati açısından özellikle küçük çocukların sağlıklı gelişimi için düzenli hayat geçirmeleri gerekmektedir. Fakat, anne ve babanın ayrı kalma veya boşanma hâlinde çocukların bir süre annede bir sürü babada kalması çocuğun menfaati aleyhine olduğu gibi lehine de olabilir.

\section{Birlikte Velâyet Ilkesi}

Evlilik devam ettikçe ve velâyetin kaldırımasını gerektiren bir sebep olmadıkça anne ve baba velâyeti birlikte kullanırlar $^{79}$. Anne ve baba velâyeti bir bütündür ve eşit kabul edilir. EMK m.263'te çocukla ilgili anne ve baba arasında anlaşmazlık doğduğu zaman babanın görüşü geçerli sayılmıştır, fakat yürürlükteki Türk Medeni Kanunu de bu hükme yer verilmemiştir ${ }^{80}$. Kanun koyucu kadın erkek eşitliğine uygun olarak anne ve babaya eşit söz hakkı tanımıştır. Böylece çocuğun yetiştirilmesi, bakımı, eğitimi ve bunun gibi önemli konularda iki tarafın ortak aldığı bir karar çocuğun menfaatine en uygun karar olarak görülmüştür.

Anne veya babadan her ikisinin de rızası alınmadan velâyetin kullanılmasına ilişkin hukukî işlem yapılamaz. Yapıldığı takdirde diğer tarafın rızası alınana kadar "askıda hükümsüzlük" söz konusu olur. Görüşü alınmayan tarafın rızasına göre askıda olan hüküm icazet ile ortadan kalkar veya kesin hükümsüz hale gelir ${ }^{81}$.

Bazı durumlarda anne veya babadan birinin velâyeti fiilen kullanması imkânsız olabilir. Örneğin; babanın askere gitmesi, tutuklanması, iş nedeniyle

77 Çetinkaya, Volkan, İnsan Hakları Hukuku Açısından Velâyet Hakkı, YL Tezi, Marmara Üniversitesi, İstanbul 2009, s. 55; Görgeç, s.22; Zeybek, s. 9; Karakayalı, s. 25;

78 Karakayalı, s. 25; Özer Taşkın, Özden, Velâyet Çocuğun Yüksek Yararı İlkesi, YL Tezi, Anadolu Üniversitesi, Eskişehir 2006, s. 34.

79 Hatemi/ Kalkan Oğuztürk, s.183; Zeybek, s.7; Görgeç, s. 24; Öztürk, s. 7; Öztürkmen İcan, s.69; Polat, Oğuz/ Güldoğan, Evin, Uzman Görüşünün Boşanma Davalarında Velâyetin Saptanmasındaki Önemi, TBB Dergisi 2015 (118), s.245.

80 Zeybek, s.7; Görgeç, s. 24; Öztürk, s. 7; Hatemi/ Kalkan Oğuztürk, s.184; Serozan, s.254.

81 Hatemi/ Kalkan Oğuztürk, s.184. 
yurtdışında olması, hastalık vb. durumlarda velâyet eşlerden biri tarafından kullanılabilir. Ancak, önemli hususlarda karşı tarafla iletişime geçme imkânı mevcut ise, karşı tarafın da fikrinin alınması gerektiği öne sürülmektedir ${ }^{82}$.

Anne ve babadan birisinin hastalığı, akıl zayıflığı, kötü hâli veya aileden uzak kalması velâyetin kullanılmasını önemli ölçüde aksatıyorsa, bir taraf velâyeti tek başına kullanır ve böylece karşı tarafın velâyeti kullanma hakkı ortadan kalkacaktır. Anne ve baba velâyeti kullanırken gerekli özeni ve titizliği göstermekle yükümlüdürler. Bu özen ve titizliğin çocuğun menfaatine uygun olması gerekmektedir. Aksi halde velâyet kötüye kullanmış sayılacaktır ${ }^{83}$.

Anne ve baba çocuğun ruhsal ve fiziksel gelişimini sağlamakla yükümlüdür. Yukarıda da bahsedildiği gibi çocuğun kişiliği, sağlıklı gelişmesi sadece çocuk için değil, toplum için de büyük önem arz etmektedir ${ }^{84}$.

\section{Kişiye Sıkı Sıkıya Bağlılık İlkesi}

Velâyet kişiye sıkı sıkıya bağlıdır ve başkasına devredilemez, mirasçılara geçmez, çocuğun rızası olsa dahi kısmen veya tamamen bundan feragat edilemez ${ }^{85}$. Yani anne ve baba velâyetle ilgili bir anlaşma veya bu hakkı kullanmayacaklarına dair bir sözleşme yapamazlar. Çünkü velâyet anne ve baba çıkarlarını değil, çocuğun menfaati için tanınmıştır ${ }^{86}$.

Öğretide bir görüşe göre, velâyetin kullanımı anne ve baba dışında birilerine bırakılabilmektedir ${ }^{87}$. Ancak, velâyetin tamamı değil, sadece kullanımı devredilebilmekte ve anne ve baba istediği zaman geri alabilmektedir. Örneğin; çocuk eğitimi ve terbiyesi okulun öğretmenlerine bırakılması durumlarında, velâyet hakkının kullanılmasının devredildiği ifade edilmektedir.

\footnotetext{
82 Zeybek, s.7; Görgeç, s. 24; Öztürk, s. 7.

83 Hatemi/ Kalkan Oğuztürk, s.184.

84 Hatemi/ Kalkan Oğuztürk, s.184.

85 Serozan, s.251; Görgeç, s.29; Zeybek, s.9; Özer Taşkın, s.35; Çetinkaya s.12-13;

Karaca, s.8; Dural, Mustafa/ Öğüz, Tufan/ Gümüş, Mustafa Alper, Türk Özel Hukuku, Aile Hukuku, C.3, 13.Baskı, İstanbul 2018, s.352.
}

86 Serozan, s.250; Görgeç, s.29; Zeybek, s.9.

87 Görgeç, s.29; Zeybek, s.9. 


\section{B. RUS HUKUKUNA GÖRE VELÂYETE HÂKIM OLAN ILLKELER}

\section{Velâyet Altındakilerin Hak ve Menfaatlerinin Korunması İlkesi}

RVVFK 5inci maddesinde Rus Hukukunda velâyete ilişkin temel ilkeler verilmiştir. Bunlar; velâyet altındakilerin hak ve menfaatlerinin korunması, velâyeti üstlenme ve velâyetten vazgeçme özgürlüğü ilkesi ve velâyetin kontrolü ilkesidir. Velâyetin en temel ilkelerinden birisi de velâyet altındaki çocuğun hak ve menfaatlerinin korunmasıdır ${ }^{88}$.

Çocukla ilgili herhangi bir işlemde çocuğun menfaati ön planda tutulmalıdır. Çocuğun menfaati doğrultusunda Rus hukukunda ayrı bir düzenleme yoktur. Ancak, kanundaki farklı düzenlemelerden çocuğun menfaatine önem verildiği görülebilir.

Velâyet altındaki çocuk veli ile birlikte yaşamalıdır. Ancak, çocuğun menfaatine uygun olduğu durumda, Velâyet ve Vesayet Kurumunun izni ile, çocuk, veliden ayrı yaşayabilir ${ }^{89}$.

RAK m.148.1/5'e göre, çocuğun menfaatine aykırı olmadığı sürece veli, çocuğun kendi anne ve babası ile veya akrabaları ile görüşmesini engelleyemez. Görüldüğü gibi söz konusu kanunda tüm kurallar çocuğun menfaati doğrultusunda düzenlenmiştir.

\section{Velâyeti Üstlenme ve Velâyetten Vazgeçme Özgürlüğü IIlkesi}

Veli, velâyeti kendi isteği ile üstlenir ve kendi isteği ile velâyetten vazgeçebilir. Veli kendi isteği ile velâyetten doğan hak ve görevlerinden vazgeçtiği durumda, velâyet sona erecektir. Bu nedenle velâyetten vazgeçmek velinin hakkıdır ${ }^{90}$.

\section{Velâyetin Kontrolü ilkesi}

Rus Hukukuna göre, velâyetin hâkim olduğu bir başka ilke velâyetin kontrolüdür. RVVFK m.24 gereği, velâyet kendisine bırakılan kişi, Velâyet ve Vesayet Kurumunun sürekli kontrolü altındadır. Velâyet ve Vesayet Kurumu düzenli ve devamlı olarak velâyet altındaki çocuğun yaşamını, velinin görevlerini yerine getirip getirmediğini, mallarının harcanıp harcanmadığını kontrol eder.

\footnotetext{
88 Рузакова, s.147; Войтович, s.140.

89 Попова, s.36; Крашеников, s.117.

90 Войтович, s.142; Рузакова, s.149; Попова, s.61.
} 


\section{VELÂYETIN KAPSAMI VE KULLANIMI}

\section{A. TÜRK HUKUKUNA GÖRE VELÂYETIN}

\section{KAPSAMI VE KULLANIMI}

Velâyet kapsamının sınırları yasa ile belirlenmiştir (TMK m.339-345). Velâyetin kapsamına, çocuğun şahısvarlığı ve çocuğun malvarlığı ile ilgili hak ve yükümlülükler girmektedir ${ }^{91}$. Çocuğun menfaatini göz önünde tutarak, velâyet; egemenlik, çocuğun adını koyma, çocuğun yerleşim yerini belirleme, çocuğu yetiştirme, eğitme, dinî eğitim, mallarını koruma, üçüncü kişilere karşı temsil etme gibi önemli konuları kapsamaktadır ${ }^{92}$.

\section{1. Çocuğun Şahısvarlığı Bakımından Velâyetin Kapsamı}

\section{a. Egemenlik Hakkı}

Anne ve babanın çocuğun üzerinde egemenlik hakkı vardır. Bu hak mutlak haklardandır ve zamanaşımına tâbi değildir ${ }^{93}$. Ancak, bu egemenlik hakkı anne ve babaya çocuğa yönelik bir uslandırma hakkı vermez ${ }^{94}$. Velâyet sadece anne ve babaya tanınmış bir iktidardı ${ }^{95}$. Haksız yere çocuğu, anne ve babadan kimse alamaz. Haksız yere kendilerinden çocuğu alınan anne ve baba, çocuğu kendilerine geri almak için herhangi bir zamanaşımı söz konusu olmadan dava açabilirler ${ }^{96}$. Yani aradan ne kadar zaman geçerse geçsin, velâyet hakları devam ettiği müddetçe anne ve baba çocuğun velâyetini talep etme hakkına sahiptir. Üçüncü bir kişi, mahkeme kararı veya idarî

91 Helvacı/ Erlüle, s.196; Akıntürk/ Ateş Karaman, Aile s.410; Gökçe, s.61; Zeybek, s.17.

92 Kılıçoğlu, Medenî, s.324; Akıncı/ Demir Gökyayala, s.147; Zeybek, s.17.

93 Akıntürk/ Ateş Karaman, Aile, s.410; Gökçe, s.61; Zevkliler/ Havutçu, s.316; Hatemi/ Kalkan Oğuztürk, s.189.

Arat, s.277.

95 2.HD, 08.05.1997, E.1997/4971, K.1997/4953: “...Medeni Kanunu'muzun hükümlerine göre, küçüklerin ve mal varlıklarının bakım ve korunmalarını sağlamak için onların malları ve şahısları üzerinde anne ve babanın sahip oldukları görevlerin ve hakların hepsine birden velâyet denmektedir. Velâyet sadece anne ve babaya tanınmış bir iktidardır..." (Çelik, Cemil, Velâyetin Kaldırılması, AÜHFD, C.54, S.1, 2005, s.261).

96 Zevkliler/ Havutçu, s.316; Akıntürk/ Ateş Karaman, Aile, s.410; Hatemi/ Kalkan Oğuztürk, s. 189. 
tedbir kararı gibi haklı bir sebep olmaksızın, çocuğu yanında bulunuduruyorsa, çocuğu anne ve babaya geri vermekle yükümlüdür97 ${ }^{97}$

Çocuk anne ve babanın sözünü dinlemelidir. Anne ve babanın rızası olmadan evi terk edemez ve yasal neden olmadıkça anne ve babadan velâyet alınamaz ${ }^{98}$. Anne ve baba; çocuğun, anne ve babasının rızası olmadan evi terk etmesini engelleyebilir. Çünkü çocuğun ergin olmadan tek başına yaşaması çocuğun menfaatine aykıııdır.

\section{b. Çocuğun Adı ve Soyadı}

TMK m.339/5'e göre, çocuğun adını anne ve baba koyar. Burada söz konusu çocuğun ön adıdır. Çocuğun adını koymak hem haktır hem de yükümlülüktür. Hiçbir çocuk isimsiz kalamaz ${ }^{99}$. Velâyet hakkına kim sahip ise çocuğun adını o kişi koyar ${ }^{100}$. Çocuğun menfaatine aykırı olmadığı ve hayatını olumsuz etkilemeyeceği sürece anne ve baba çocuğa diledikleri ismi koyabilirler ${ }^{101}$.

Anne ve baba çocukla ilgili bazı konularda anlaşamıyorlar ise EMK m.263'e göre, babanın görüşü üstün kabul edilmekteydi. Fakat 4721 sayılı Medeni Kanun kadın-erkek eşitliğini zedeleyen bu kuralı kaldırmışıır ${ }^{102}$. Anne ve babaya çocuğun adını koyma konusunda anlaşmak zorunlu kılınmıştır. Anne ve baba, çocuğun adını koymakta anlaşamıyorlarsa her ikisi de istediği ismi koyma haklarına sahiptirler. Anne ve baba birbirlerinin seçtiği ismi koymak istemiyorlarsa, hâkime başvurabilirler ${ }^{103}$. Hâkim kararı ile iki taraftan birinin görüşü kabul edilir veya hâkim kendisi bir çözüm bulur. TMK m.195/2 gereği hâkim, eşleri yükümlülükleri konusunda uyarır; onları uzlaştırmaya çalışır ve eşlerin ortak rızası ile uzman kişilerin yardımını isteyebilir.

\footnotetext{
97 Akıntürk/ Ateş Karaman, Aile, s.410, Zeybek, s.19.

98 Zeytin/ Ergün, s.210; Hatemi/ Kalkan Oğuztürk, s. 189; Görgeç, s.31.

99 Hatemi/ Kalkan Oğuztürk, s. 189.

100 Dural/ Öğüz/ Gümüş, s.355; Helvacu/ Erlüle, s.196; Akıntürk/ Ateş Karaman, Aile, s.410.

101 Grassınger, Gülçin Elçin, Türk Medeni Kanunu'nda Yer Alan Velâyet Hükümleri Kapsamında Küçüğün Kişi Varlığının Korunması İçin Alınacak Tedbirler, 1.Baskı, İstanbul 2009, s.39.

102 Arat, s.278; Akıntürk/ Ateş Karaman, Aile, s.410; Zeybek, s.22.

103 Akıntürk/ Ateş Karaman, Aile, s.410; Hatemi/ Kalkan Oğuztürk, s. 189; Zeytin/ Ergün, s.210; Görgeç, s.31.
} 
Bazı görüşlere ${ }^{104}$ göre, çocuğun adının koyulmasının velâyetle bir ilgisi yoktur ve anne ve baba velâyete sahip değilse de çocuğun adını koyma hakkına sahiptirler. Diğer bir görüş ise bu görüşe katılmamaktadır ${ }^{105}$. Bu yazarlar, şayet böyle olsaydı çocuğun adı ile ilgili düzenlemelerin Türk Medeni Kanunu'nun altıncı ayırımda değil beşinci ayırımında yer almaları gerektiğini savunmaktadırlar ${ }^{106}$.

TMK m.321 gereği anne ve baba evliyse çocuk ailenin soyadını alır. Bu da babanın soyadıdır. Maddenin devamında anne ve baba evli değilse çocuk annesinin soyadını taşır diye düzenlenmiştir. Fakat Anayasa Mahkemesi 02.07.2009 tarihli kararıyla "..evli değilse anne soyadını taşır" hükmünü Anayasa'nın 10,11 ve 41 maddelerine aykırı bularak iptal etmiştir ${ }^{107}$. Anayasa Mahkemesinin bu kararından çok önce yürürlüğe giren Nüfüs Hizmetleri Kanunu m.28/4 ve geçici m.5 gereği, evlilik dışı doğan fakat baba ile hukuken soybağı ilişkisi kurulan veya baba tarafından tanınan çocuk, babasının soyadını alma hakkına sahiptir. Baba tarafından tanınmamış veya soybağı ilişkisi kurulmamış çocuk ise ana soyadını taşıyacaktır ${ }^{108}$. Güncel Yargıtay kararına göre, boşanmış kadın; velâyeti kendisine verilmiş olan çocuğuna "kendi soyadını" verilmesini velâyet hakkına dayanarak Aile Mahkemesinden isteyebilir ${ }^{109}$.

104 Akıntürk/ Ateş Karaman, Aile, s.410; Zeybek, s.22.

105 Akıntürk/ Ateş Karaman, Aile, s.410;

106 Akıntürk/Ateş Karaman, Aile, s.410.

107 RG. 07.10.2009-27396.

108 Akyüz, s.120-121; Dural/Öğüz/ Gümüş, s341.

109 Y. 2.HD, 9.04.2018, E.2018/1306, K.2018/4719: “..velâyet hakkına sahip davacı anne, soyadlarının farklı olmasından çocuğun rahatsız olduğunu ve anne ile aynı soyadını taşımak istediğini ileri sürmüş olup, davacı tanıkları da davalı babanın çocuğuna ilgisiz olduğunu, yaklaşık üç yıldır babanın çocuğunu görmeye gelmediğini, çocuğun birlikte yaşadığı anne ile aynı soyadını taşımamaktan rahatsı olduğunu, anne ile aynı soyadını taşımak isteğini sürekli dile getirdiğini, kendisini tanıtırken soyadını annenin soyadı olan "..." olarak ifade ettiğini beyan etmişlerdir. Çocuğun soyadının annenin soyadı ile değiştirilmesi halinde çocuğun üstün yararı bakımından ruhsal gelişiminin olumsuz etkileneceği ileri sürülmediği gibi, az önce açıklanan tanık beyanlarından çocuğun soyadııın annenin soyadı olarak değiştirilmesinin çocuğun üstün yararına olabileceği anlaşılmaktadır (http://www.kazanci.com.tr/) Erişim tarihi 14.10.2018. 


\section{c. Çocuğun Yerleşim Yeri}

TMK m.21/1'e göre, çocuğun oturma yeri onun yerleşim yeridir. Velâyet altında bulunan çocuğun yerleşim yeri anne ve babanın yerleşim yeridir $^{110}$. Anne ve babanın ortak yerleşim yeri yoksa çocuğun kendisine bırakılan tarafın yerleşim yeri çocuğun yerleşim yeridir ${ }^{111}$. Erginliğe erişmemiş çocuk, anne ve baba rızası ile onların yerleşim yeri dışında bir yerde yaşıyorsa veya çalışıyorsa, çocuğun kendi seçtiği yerin, çocuğun yerleşim yeri olarak kabul edilmesi gerektiği ileri sürülmektedir ${ }^{112}$. Bu konuda, ana unsur çocuğun menfaatidir. Eğer çocuğun anne ve babadan ayrı yaşaması, çocuk için daha yararlı olursa, anne ve baba çocuğun ayrı yaşamasına karşı olmamaları gerekmektedir.

\section{d. Çocuğun Yetiştirilmesi ve Eğitimi}

Anne ve baba çocuğun yetişitirilmesi ve eğitilmesi konusunda hak ve yükümlülüklere sahiptir ${ }^{113}$. Türk Medeni Kanunu çocuğun eğitimi ve dinî eğitimi konusunda anne ve babanın hak ve yükümlülüklerini belirtmiştir. TMK m.339/1'e göre, anne ve baba, çocuğun bakım ve eğitimi konusunda çocuğun menfaatini göz önünde tutarak gerekli kararları alır ve uygularlar.

Eşler ergin olmayan üvey çocuklarına özen ve ilgi göstermekle yükümlü olduklarından, çocuğun eğitimi ve yetiştirilmesinde de özen göstermeleri ve eşlerine yardım etmeleri gerekmektedir ${ }^{114}$. Yetiştirme ve eğitme hakkı velâyet kapsamında yer alan hak ve yükümlülük olduğundan, velâyetin sona ermesi, çocuğun erginliğe erişmesi ile birlikte bu hak da kendiliğinden sona erecektir ${ }^{115}$. Erginliğe erişmiş çocuğun eğitimi devam ediyorsa, eğitim süresi bitinceye kadar anne ve baba çocuğa bakmakla

110 Helvacu/ Erlüle, s.196; Görgeç, s.34; Zevkliler/ Havutçu, s. 316; Akıntürk/ Ateş Karaman, Aile, s.410.

111 Zevkliler/ Havutçu, s. 316; Helvacı/ Erlüle, s.196; Akıntürk/ Ateş Karaman, Aile, s.410; Görgeç, s.34.

112 Akıntürk/ Ateş Karaman, Aile, s.410; Görgeç, s.34; Zeybek, s.23.

113 Kılıçoğlu, Medenî, s.324; Zevkliler/ Havutçu, s. 316; Hatemi/ Kalkan Oğuztürk, s. 189; Akıntürk/ Ateş Karaman, Aile, s.412.

114 Zevkliler/ Havutçu, s. 316; Zeybek, s.13.

115 Hatemi/ Kalkan Oğuztürk, s. 190; Akıntürk/ Ateş Karaman, Aile, s.412. 
yükümlüdür ${ }^{116}$. Kanunda belirtildiği gibi çocuğun eğitimi, genel eğitimle birlikte meslekî ve dinî eğitimi de kapsamaktadır.

\section{aa. Genel Eğitim ve Meslekî Eğitim}

Çocuğun eğitimi öncelikle ailede başlar. Çocuğun genel eğitimi ilk olarak çocuğun erdemli, onurlu, vatanı ve milletini seven, dürüst ve namuslu bir insan olarak yetiştirilmesidir. Çocuk eğitimi; çocuğun sosyal ve ahlâki açıdan iyi şeyler öğrenmesi için ve kötü yollara düşmesini engellemek için olmalıdır ${ }^{117}$.

Çocuğun genel eğitimi tamamladıktan sonra, anne ve baba çocuğu anayasa ve kanunlar gereği okulda eğitim almasını sağlamaları gerekmektedir. AY m.42'ye göre, kimse eğitim hakkından yoksun bırakılamaz. Anne ve baba çocuğun ilk ve orta eğitim almasını sağlamakla yükümlüdür ${ }^{118}$.

TMK m.340 gereği, anne ve baba çocuğu olanaklarına göre, eğitirler ve onun bedensel, zihinsel, ruhsal, ahlâki ve toplumsal gelişimini sağlamak ve korumakla yükümlüdürler. Anne ve baba çocuğa, özellikle bedensel ve zihinsel özürlü olanlara, yetenek ve eğilimlerine uygun düşecek ölçüde, genel ve meslekî eğitim sağlamaları gerekmektedir. Anne ve baba çocuğu yetiştirme ve eğitme konusunda çocuğun menfaatini göz önünde bulundurarak, olgunluğu ölçüsünde hayatını düzenlemeye fırsat tanımaları lâzımdır ${ }^{119}$.

Anne ve baba çocuğa meslekî eğitim vermekte yükümlüdür. Eski Medeni Kanun meslekî eğitimi konusunu ayrı bir maddede düzenlemişken yürürlükteki Türk Medeni Kanunu genel eğitim ve meslekî eğitimi aynı madde altında düzenleyip, dinî eğitimi ayrı madde olarak düzenlemiştir. Yukarıda da belirttiğimiz gibi TMK m.340/2'de anne ve baba çocuğa genel eğitimle birlikte meslekî eğitim vermekte yükümlü olduğunu göstermiştir. Meslekî eğitim konusunda da anne ve babanın çocuğa uygun bir meslek seçmekte gayret göstermeleri gerekmektedir. Fakat çocuğun isteğini de dikkate almaları gerekmektedir. Eğer çocuğun ressam veya heykeltraş olma

116 Kılıçoğlu, Ahmet, Medenî Kanun'umuzun Aile - Miras - Eşya Hukukuna Getirdiği Yenilikler, 2.Bası, Ankara 2004, s.137.

117 Akıntürk/ Ateş Karaman, Aile, s.412; Zeybek, s.27.

118 Hatemi/ Kalkan Oğuztürk, s. 190.

119 Zevkliler/ Havutçu, s. 316; Zeybek, s.27. 
isteği ve yeteneği varsa, ancak, anne ve baba çocuğa kendi mesleklerini kabul ettirmeye zorlarsa, çocuk hâkime başvurarak, gerekli önlemleri alınmasını isteyebilir ${ }^{120}$.

\section{bb. Dinî Eğitim}

Çocuğun dinî eğitimini belirlemek de anne ve babaya aittir ${ }^{121}$. Anne ve babanın bu hakkını sınırlayan veya kaldıran kendi aralarında yapılan veya üçüncü kişilerle yapılan her türlü sözleşmeler geçersizdir. Anne ve babanın çocuğun eğitimini belirlemesi, çocuk ergin olana kadar devam eder ${ }^{122}$. Çocuk erginliğe ulaştıktan sonra dinîni seçmekte özgürdür ${ }^{123}$.

Anne ve babanın çocuk eğitimi konusunda anlaşmaları gerekmektedir. Örneğin; anne hristiyan, baba da müslüman olup, çocuğun eğitimi konusunda anlaşmazlığa düşüyorlarsa, anne ve baba hâkime başvuru yapacaklardır. TMK m.346 gereği, hâkim uygun önlemleri alacaktır ${ }^{124}$.

Çocuk anne veya babadan birinin velâyeti altında bulunuyorsa, çocuğun dini eğitimini velâyete sahip olan taraf belirleyecektir. Çocuğun velâyeti kendine bırakılmayan taraf ise çocuğun dini eğitimini belirlemede müdahele hakkı yoktur ${ }^{125}$.

\section{2. Çocuğun Malvarlığı Bakımından Velâyetin Kapsamı}

Çocuğun malları velâyete sıkı sıkıya bağı bir konu olsa da, Türk Medeni Kanununda velâyetten ayrı başık altında 352-363 maddeleri arasında düzenlenmiştir. Kanun, çocuğun mallarının yönetilmesi, kullanılması, sarf edilmesi ve kısmen sarf edilmesi, korunması, çocuğun serbest malları konularını ayrıntılı bir şekilde düzenlemiştir.

120 Zeybek, s.28; Akıntürk/ Ateş Karaman, Aile, s.413.

121 Zeytin/ Ergün, s.210; Zevkliler/ Havutçu, s.316; Hatemi/ Kalkan Oğuztürk, s.190; Akıntürk/ Ateş Karaman, Aile, s.413; Grassınger, s.36: Yavuz, Cevdet, Türk Medeni Kanunu, 11.Baskı, İstanbul 2014, s.313.

122 Dural/ Öğüz/ Gümüş, s.356; Akıntürk/ Ateş Karaman, Aile, s.414; Zeybek, s.30;

123 Kılıçoğlu, Medenî, s.325; Hatemi/ Kalkan Oğuztürk, s. 190; Zeytin/ Ergün, s.210; Zeybek, s.30.

124 Akıntürk/ Ateş Karaman, Aile, s.413.

125 Zeybek, s.29; Akıntürk/ Ateş Karaman, Aile, s.413. 


\section{a. Çocuğun Mallarının Yönetilmesi}

\section{aa. Yönetim Hakkı ve Yükümlülüğü}

Çocuğun mallarının yönetimi TMK m.352'ye göre, velâyet devam ettiği sürece anne ve babaya aittir. Velâyete sıkı sıkıya bağlı olan çocuğun mallarının yönetimi bir hak ve yükümlülüktür. Anne ve baba çocuk mallarını yönetim esnasında kural olarak hesap ve güvence vermezler ${ }^{126}$. Ancak, yükümlülüklerini yerine getirmedikleri durumlarda hâkimin müdahale yetkisi vardır. Anne ve baba bu haktan feragat edemezler veya bu hakkı başka birisine devredemezler. Anne ve baba, bu hakkı birlikte kullanırlar ${ }^{127}$.

Yönetim hakkı, çocuğun serbest malları dışında kalan tüm mallarını kapsamaktadır. Yönetim hakkının kullanılması, yönetim kapsamına giren bu mallar üzerinde fiili egemenliği de gerektirdiği içindir ki, anne ve baba çocuğun mallarının zilyedidirler ${ }^{128}$.

Anne ve baba çocuğun mallarını kiraya verebilir, kira bedelini alabilir, gerekli onarımları yapabilir ve faizleri tahsil edebilir, gerektiğinde malları satabilir, üzerinde aynî hak kurabilir ${ }^{129}$. Anne ve baba çocuk mallarını yönetmek suretiyle çocuk yararına kullanmak ve basiretli bir yönetici gibi davranmak zorundadırlar ${ }^{130}$.

\section{bb. Yönetim Hakkının Sona Ermesi}

Çocuk mallarının yönetim hakkı sona ermesinin iki nedeni vardır. Bunlar, velâyetin sona ermesi ve yönetimin anne ve babadan alınmasıdır ${ }^{131}$.

TMK m.348-349'da öngörülen durumlarda, velâyetin sona ermesi ile hâkim tarafından çocuk mallarının yönetimini her ikisinden de kaldırılabilir. Evliliğin ölüm, fesih, iptal veya boşanma sebepleri ile sona ermesi durumunda velâyet anne ve babanın ikisinden de alınmaz. Ölüm veya gaipliğe karar verilmiş olan taraf için velâyet sona ermiş olduğunda, sağ kalan taraf velâyeti kullanmaya devam edecektir. Evliliğin iptali veya boşanma

126 Görgeç, s.44; Akıntürk/ Ateş Karaman, Aile, s.422; Zeybek, s.31; Y. 2.HD, 22.04.2010, E.2010/3578, K.2010/8083 (Gençcan, Ömer Uğur, 4721 Sayılı Türk Medeni Kanunu Yorumu, Ankara 2015, 1.Baskı, s.1714).

127 Zeybek, 34; Akıntürk/ Ateş Karaman, Aile, s.421; Görgeç, s.50.

128 Dural/ Ögüz/ Gümüş, s.358; Akıntürk/ Ateş Karaman, Aile, s.421.

129 Zeybek, 35; Akıntürk/ Ateş Karaman, Aile, s.421.

130 Akıntürk/ Ateş Karaman, Aile, s.422; Zeybek, 36.

131 Görgeç, s.57-58; Akıntürk/ Ateş Karaman, Aile, s.422; Zeybek, 37. 
durumlarında, velâyet hangi tarafa bırakılırsa onun hakkı devam edecektir, diğer tarafın hakkı ise sona ermiş olacaktır ${ }^{132}$. TMK m.353 gereği, evlilik sona erince velâyet kendisinde kalan eş, hâkime çocuğun malvarlığının dökümünü gösteren bir defter vermek ve bu malvarlığında veya yapılan yatırımlarda gerçekleşen önemli değişiklikleri bildirmek zorundadır.

TMK m.361/1 gereği, çocuğun mallarının tehlikeye düşmesi başka bir şekilde önlenemiyorsa hâkim, yönetimin bir kayyıma devredilmesine karar verebilir. Bu hüküm çocuğun mallarının korunması için alınan bir önlemdir. Maddede belirtildiği gibi öncelikle hâkim tehlikeyi önlemeye ilişkin karar verebilir, mesela anne ve babadan bu konuda güvence vermelerini isteyebilir ${ }^{133}$. TMK m.351/1, bu hükme engel olamaz. Anne ve baba yönetim hakkını iyi kullanamamaları veya hakkını yerine getiremedikleri takdirde, hâkim müdahale edip, yönetimi onlardan alarak bir kayyıma devredebilir ${ }^{134}$. TMK m.361/2 gereği, yönetimi ana ve babaya ait olmayan çocuk mallarının tehlikeye düştüğü durumda, hâkim, aynı önlemlerin alınmasını kararlaştırabilir, yani, yönetimin bir kayyıma devredilmesine karar verebilir.

\section{b. Çocuk Mallarının Kullanımı}

Çocuk mallarını, anne ve baba birlikte kullanırlar. Anne ve baba çocuğa bir ücret ödemeksizin evinde oturabilir, aracını ve eşyalarını kullanabilirler. Ama kıymetli eşyalardan herhangi birine zarar verirler ise, yapılan zararı telafi etmeleri gerekmektedir ${ }^{135}$.

TMK m.354'e göre, çocuk mallarının yönetim hakkı anne ve babadan alınması veya velâyetin sona ermesi ile durdurulduğu hâllerde, velâyet anne ve babadan kusurları nedeniyle kaldırılmış olmadıkça anne ve baba çocuk mallarını kullanmaya devam edecektir ${ }^{136}$. Örneğin, velâyet anne ve babadan hastalık veya özürlüğünden dolayı alınmış olsa anne ve baba çocuk mallarını kullanmaya devam edebilirler. Anne ve baba, çocuk erginliğe erişene kadar çocuğun mallarını birlikte kullanırlar ${ }^{137}$.

132 Akıntürk/ Ateş Karaman, Aile, s.422.

133 Zeybek, 38; Akıntürk/ Ateş Karaman, Aile, s.422.

134 Görgeç, s.58; Akıntürk/ Ateş Karaman, Aile, s.422; Zeybek, 38.

135 Şener, Esat, Vesayet ve Velâyet Hukuku, Ankara 1996, s.295; Akıntürk/ Ateş Karaman, Aile, s.427.

136 Akıntürk/ Ateş Karaman, Aile, s.427; Zeybek, 41.

137 Akıntürk/ Ateş Karaman, Aile, s.427; 


\section{c. Çocuk Mallarının Harcanması}

\section{aa. Çocuk Mallarının Gelirlerinin Sarf Edilmesi}

TMK m.355/1'de kanun koyucu çocuk mallarından elde edilen gelirlerin öncelikle çocuğun bakımı, yetiştirilmesi ve eğitimi için sarfedilmesi gerektiğini düzenlemiştir ${ }^{138}$. Anne ve baba velâyeti altındaki çocukların bakımı, yetiştirilmesi ve eğitiminden sorumludurlar ve bu harcamaları bizzat kendi gelirlerinden karşılamakla yükümlüdürler ${ }^{139}$.

Anne ve baba çocuğun bakımı, yetiştirilmesi ve eğitimini karşılamakta zorlanıyorlarsa çocuk mallarından harcama yapabilirler. Anne ve baba çocuk mallarını hakkaniyete uygun ölçüde ailenin ihtiyaçları için de harcama yapabilirler. Ancak, ailenin sosyal ve ekonomik durumuna karşı çocuğun getirdiği ekonomik yükler ölçüsünde harcamaları gerekmektedir ${ }^{140}$. Örneğin; çocuk mallarının büyük bir kısmı aile ihtiyaçlarına harcanarak, çocuğun bakımı veya eğitimine para yetersiz kalırsa anne ve baba hakkaniyet sınırlarını aşmış sayılır. Çocuğun mallarından elde edilen gelirlerden çocuğun bakımı, yetiştirilmesi, eğitimi ve aile ihtiyaçlarına harcanan kııımından artanı, çocuk mallarına katıı ı ${ }^{141}$. Anne ve baba çocuk mallarını hakkaniyete uygun olmayan ölçüde kullanırlarsa, bu durumda hâkim olaya müdahale edebilir.

\section{bb. Çocuk Mallarının Kısmen Sarf Edilmesi}

TMK m.356/1'e göre, olağan ihtiyaçların gerektirdiği ölçüde sermaye biçiminde ödemeler, tazminatlar ve benzeri edimler, çocuğun bakımı için kısmen kullanılabilir. Bu kuralda görüldüğü gibi, kanun koyucu, çocuk mallarının hepsinin değil, nitelikleri itibariyle özellik arz edenleri dikkate almış ve bunları "sermaye biçiminde ödemeler", "tazminatlar" ve "benzeri edimler" şeklinde açıkça belirtmiştir ${ }^{142}$. Ancak, bu ihtiyaçların olağan olmaları gerekmektedir. Örneğin; çocuk bir hastalığa yakalanırsa ve gerekli tedaviler için anne ve babanın gelirleri yetmiyorsa, hâkimin izni alınmadan çocuğun malları kullanılabilir.

138 Dural/ Öğüz/ Gümüş, s.359; Zeybek, 42; Akıntürk/ Ateş Karaman, Aile, s.428; Akıntürk, Turgut: Aile hukuku: Yeni Medeni Kanuna Uyarlanmış Aile Hukuku, İstanbul 2004, s.415.

139 Akıntürk/ Ateş Karaman, Aile, s.428; Zeybek, 42.

140 Akıntürk/ Ateş Karaman, Aile, s.428; Zeybek, 42

141 Zeybek, 43; Akıntürk/ Ateş Karaman, Aile, s.428; Dural/ Öğüz/ Gümüş, s.359.

142 Akıntürk/ Ateş Karaman, Aile, s.429; Zeybek, 43. 
TMK m.356/2'ye göre, çocuğun bakımı, yetiştirilmesi ve eğitimi için zorunluluk varsa, hâkim, anne ve babaya belirlediği miktar için çocuğun diğer mallarına da başvurma yetkisini tanıyabilir. Örneğin; çocuğu özel yeteneklerinden dolayı özel okula göndermek isterlerse, bu harcamalar için anne ve baba çocuğun diğer mallarından faydalanabilirler ${ }^{143}$.

\section{3. Çocuğun Temsili Bakımından Velâyetin Kapsamı}

TMK m.342/1 gereği, anne ve baba, velâyeti yürütme hakkına sahip bulundukları sürece ve velâyet çerçevesinde kalmak üzere üçüncü kişilere karşı çocuklarının yasal temsilcisidirler. Anne ve babanın, hâkimin iznine gerek olmadan çocuğu temsil etme, onun adına hareket etme hakları $v a^{2} d{ }^{144}$. Üçüncü kişilerle yapılacak hukukî işlemlerde kural olarak anne ve babanın her ikisinin rızası şarttır ${ }^{145}$.

Vesayet sorumluları bazı hukuki işlemlerin yapılması için vesayet ve denetim makamlarından izin alması gerekirken, veliler mahkemeye başvuru yapmadan hukukî işlemleri yapabilmektedir ${ }^{146}$. Bununla birlikte, TMK m.342/2 gereği, iyiniyetli üçüncü kişilere anne ve babadan birisinin rızası ile işlem yapabilmektedir. Örneğin; anne ve babanın rızası ile yatılı okula yerleştirilen çocuğun işlemlerini okul veya yurt sorumlusu gerçekleştirecektir.

Çocuk ayırt etme gücüne sahip değilse, onun yerine bütün hukukî işlemleri velâyete sahip anne ve baba yapar. Ayırt etme gücüne sahip olan çocuklar kendilerini borç altına sokmayan işlemleri yasal temsilcileri olmadan yapabilirler. Fakat çocuk, anne ve baba izni ile veya sonradan vereceği onay ile borç altına girebilir ${ }^{147}$.

Anne ve baba çocuk adına tasarruf işlemi yapabilir ya da onu borç altına sokan işlemler yapabilirler. Ancak, ayırt etme gücüne sahip olan çocuğun görüşü ve düşünceleri göz önüne alınmalıdır ${ }^{148}$.

TMK m.345/3'e göre, vesayet makamlarının iznine bağlı hususlar dışında kısıtıların temsiline ilişkin hükümler velâyetteki temsilde de

\footnotetext{
143 Akıntürk/ Ateş Karaman, Aile, s.428.

144 Dural/ Öğüz/ Gümüş, s.357; Akıntürk/ Ateş Karaman, Aile, s.428; Zeybek, 56.

145 Hatemi/ Kalkan Oğuztürk, s. 192; Zeybek, 43.

146 Akıntürk/ Ateş Karaman, Medeni, s.302; Zeybek, s.57.

147 Helvacl/ Erlüle, s.197; Hatemi/ Kalkan Oğuztürk, s. 192.

148 Hatemi/ Kalkan Oğuztürk, s. 192; Zeybek, s.56.
} 
uygulanır. Bu kuraldan gördüğü gibi erginliğe erişen kısıtlı çocuklar vasi atanmadan velâyetin anne ve babaya verildiği durumlarda da, anne ve baba vesayet makamlarından izin almaksızın çocuk adına işlemler yapabilmektedir ${ }^{149}$.

\section{a. Çocuk ile Anne ve Baba Arasında Yapılan veya Çocuk ile Üçüncü Kişi Arasında Anne ve Baba Yararına Yapılan Hukukî İşlemler}

Çocuk ile anne ve baba arasında hukukî işlemler düzenlenebilir. Gerek çocuk anne ve babası ile gerekse üçüncü kişilerle anne ve babanın yararına hukuken geçerli işlemler yapabilir ${ }^{150}$. TMK m.345 uyarınca, çocuk ile anne ve baba arasında, ya da anne ve babanın menfaatine uygun olarak çocuk ile üçüncü kişi arasında yapılacak bir hukukî işlemle çocuğun borç altına girebilmesi, bir kayyımın katılmasına ve hâkimin onayına bağlıdır. Bu durumlarda, çocuk menfaatini göz önüne alarak, çocuk ile anne ve baba arasında ya da onların lehine üçüncü kişiler arasında menfaat çatışması ortaya çıkarsa, çocuğa bir kayyım atanması ya da hâkimin onayı gerekir ${ }^{151}$. Onayı aile mahkemesi hâkiminin vermesi gerekmektedir ${ }^{152}$. Örneğin, çocuk mallarının anne ve babaya satılması, anne ve babanın borcu için çocuk mallarının rehin göstermesi olması gibi durumlar söz konusu olur.

\section{b. Çocuğun Fiil Ehliyeti}

Fiil ehliyeti kişinin kendi fiilleri ile hak sahibi olabilmesi ve borç altına girmesi gibi durumlarda kendi adına karar verebilmesi demektir. TMK m.342/1'e göre, velâyet altındaki çocuğun fiil ehliyeti, vesayet altındaki kişinin ehliyeti gibidir, yani sınırsız ehliyetsizdir. Çocuk, borçlarından kendi malvarlığı ile sorumludur. Anne ve baba üçüncü kişilere karşı çocuğun, yasal temsilcisi olmakla birlikte, onların temsil yetkileri, sınırlı ehliyetsizler ve tam ehliyetsizlerin temsiline ilişkin hükümlere tâbidir ${ }^{153}$. Sınırlı ehliyetsiz konumunda olan çocuk adına yapılacak işlemlerde çocuğun temsili açısından, kural olarak, vasinin kısıtlıyı temsil etmesine ilişkin hükümler uygulanır ${ }^{154}$. Ancak TMK m.462 ve m.463'te belirtilen işlemler için vasi

\footnotetext{
149 Zeybek, s.57.

150 Kılıçoğlu, Medenî, s.325.

151 Zeytin/ Ergün, s.211; Hatemi/ Kalkan Oğuztürk, s. 193; Kılıçoğlu, Medenî, s.325.

152 Tutumlu, s.1382; Akıntürk/ Ateş Karaman, Aile, s.438; Zeybek, s.83.

153 Hatemi/ Kalkan Oğuztürk, s. 191; Zeybek, s.52.

154 Dural/ Öğüz/ Gümüş, s.356; Hatemi/ Kalkan Oğuztürk, s. 190.
} 
vesayet veya denetim makamınndan izin almak zorundadır, veli ise bu işlemleri izinsiz yapabilir.

Ayırt etme gücüne sahip çocuk sınırlı ehliyetsiz, ayırt etme gücüne sahip olamayan çocuk tam ehliyetsizdir ${ }^{155}$. Tam ehliyetsiz çocukların yaptıkları hukukî işlemler hukukî sonuç doğurmaz ve yaptığı haksız fiiller, kural olarak borca aykırı davranışlardan dolayı sorumlu tutulmazlar ${ }^{156}$. Ayırt etme gücüne sahip olmayan çocuğun meydana getirdiği zararlardan, hakkaniyet gerektirdiği takdirede, veli sorunlu tutulabilir. Örneğin, zengin çocuk oynarken yoksul iş̧̧inin evini yakarsa, çocuğu gözetmekle gerekli özeni göstermediği için veli sorumlu tutulacaktır ${ }^{157}$.

Çocuklar adına hukukî işlemleri yasal temsilcileri yapar ${ }^{158}$. Sınırlı ehliyetsiz çocuklar, hukukî işlemleri yasal temsilcilerinin rızası ile yaparlar veya tek başlarına hareket edebilirler. Borç altına girmeleri durumunda ise çocuğun anne ve babası yasal temsilci olarak sorumlu tutulur ${ }^{159}$.

\section{c. Anne ve Babanın Temsil Yetkisinin Kaldııılığı Hâller}

Anne ve baba, çocuk yararına uygun olup olmadığına bakmaksızın kanun tarafından açıkça yasaklanmış hukukî işlemleri çocuk adına temsil yetkisini kullanarak yapamazlar, ne çocuğun yaptığı bu işlemlere onay vererek işlemi geçerli hale getiremezler ${ }^{160}$. TMK m.449'da belirtilen işlemler velâyet için de geçerlidir. Anne ve baba çocuk adına ve hesabına kefalet sözleşmesi yapamaz, vakıf kuramaz ve önemli bağışlarda bulunamaz ${ }^{161}$.

Evlenme, nişanlanma, erken erginlik için mahkemeye başvurma, derneğe üye olma gibi işlemler kişiye sıkı sıkıya bağı haklardan olduğu için, çocuk adına bu işlemleri anne ve baba gerçekleştiremez ${ }^{162}$. Ama bu hakların niteliği gereği çocuk da kendi başına gerçekleştiremez. Bu işlemleri çocuk anne ve baba izni veya icazet ile gerçekleştirir ${ }^{163}$.

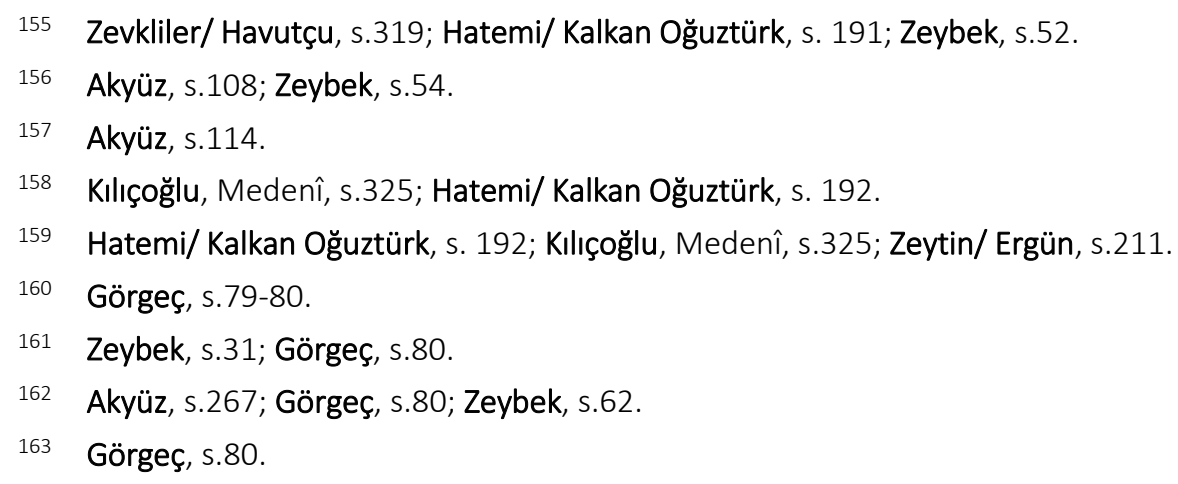


Evlilik dışı doğan çocuğu tanıma kişiye sıkı sıkıya bağlı haklardandır ve bu işlemi çocuk adına anne ve baba tek başına yapamazlar ${ }^{164}$. Tanıma hakkı sadece biyolojik babaya verilmiştir ${ }^{165}$. TMK m.295/2 gereği tanıma beyanında bulunan kimse küçük veya kısıtlı ise, veli veya vasisinin de rızası gereklidir. Ancak, evlilik dışı doğan çocuğu vasîyet yolu ile tanımak için, baba 15 yaşını doldurmuş olması gerekmektedir (TMK m.502).

Ayırt etme gücüne sahip sınırlı ehliyetsiz çocuk, serbest mallarla ilgili hukuki işlemleri ve karşılıksız kazanmaları tek başına yapailir. Anne ve babanın çocuğun serbest malları üzerinde yönetim hakkı bulunmadığı için temsil yetkileri de yoktur. Bu yüzden, anne ve baba çocuğun serbest malları üzerinde herhangi bir hukukî işlem yapamaz ${ }^{166}$.

\section{B. RUS HUKUKUNA GÖRE VELÂYETIN KAPSAMI VE KULLANIMI}

\section{1. Çocuğun Şahısvarlığı Bakımından Velâyetin Kapsamı}

\section{a. Egemenlik Hakkı}

Velâyet altında bulunan çocuğu yasal neden olmadıkça veliden kimse alamaz. Yani haksız yere çocuğu, veliden kimsenin almaya hakkı yoktur. Daha önce de belirttiğimiz gibi Rus hukukunda üçüncü kişiler de veli olabilmektedir. Çocuğa anne ve babası dışında üçüncü kişi veli olarak atandığı durumlarda, çocuğun kendi anne babası veliden çocuğu geri vermesini talep edemez. Aynı şekilde, çocuk daha önce evlat edinilmişse, evlat edineneni de yasal bir neden olmadıkça çocuğu veliden alamaz ${ }^{167}$.

\section{b. Birlikte Yaşama Hakkı}

RMK m.36'ya göre, velâyet altındakiler veli ile yaşamak zorundadırlar ${ }^{168}$. Veliler, ikametgâhlarının değiştiği takdirde Velâyet ve Vesayet Kurumuna haber etmek zorundadırlar. Velâyetin doğru şekilde yerine getirilmesi veli ve çocuğun beraber yaşadığı durumda mümkündür. Çünkü beraber yaşamak, sürekli irtibatı ve sağlam iletişimi sağlayacaktır ${ }^{169}$.

\footnotetext{
164 Kılıçoğlu, Yenilikler, s.106; Akyüz, s.154; Zeybek, s.52.

165 Akyüz, s.154;

166 Zeybek, s.63; Görgeç, s.80; Akyüz, s.267.

167 Рузакова, s.147.

168 Рузакова, s.147; Попова, s.3; Войтович, s.140; Крашеников, s.117; Гомола А.И./ Гомола И.А., s.134.

169 Попова, s.36; Крашеников, s.117.
} 
Çocuğun menfaatine aykırı değilse kendi işlerini kendisi yapabilen çocuk Velâyet ve Vesayet Kurumunun izini ile veliden ayrı yaşayabilir. Kanunda net olarak hangi durumlarda çocuk veliden ayrı yaşayabileceği düzenlenmemiştir. Genelde başka şehirde yatılı okula kayıt olan çocukların veliden ayrı yaşamasına izin verilmektedir. Çocuğun veliden uzun süre ayrı kalması velâyetin kaldırılmasına sebep olabilir ${ }^{170}$.

\section{c. Çocuğun Bakım, Tedavi ve Geçinme Hakkı}

Veli, kendi velâyeti altındaki küçüklerin bakımı, tedavisi, geçinmesi ve onların hak ve menfaatlerinin korunmasından sorumludur ${ }^{171}$. Veli, velâyeti altında bulunan çocuğa kendi çocuğu gibi bakım yapmalıdır ve onun için hayatın doğal ve temel ihtiyaçlarını sağlamakla yükümlüdür ${ }^{172}$. Örneğin, yeme içme, giyim, tıbbî yardım, kitaplar, oyuncaklar vb. Bununla birlikte, kanun koyucu, veliyi, çocuğun sağlık ihtiyaçlarını da karşılamakla yükümlü tutmuştur. Ancak, bu intiyaçların neler olduğu kanunda açıkça belirtilmemiştir. Çocuğa gerekli tedaviler yapılmadığı veya gerekli yardımlar verilmediği için ortaya çıkan zararlardan veli sorumlu tutulacaktır ${ }^{173}$.

Veli çocuğu gerektiiği gibi geçindirmekle yükümlüdür. Bunun için velinin Velâyet ve Vesayet Kurumundan izin almadan çocuğa ait gelirlerden harcama yapma hakkı vardı1 ${ }^{174}$. Devlet, velâyet altındaki çocuğu geçindirilmesi için veliyi maddî olarak desteklemektedir. Örneğin, çocukları velâyet altına alanlar için Rusya Federasyonu tarafından verilen aylık miktar, çocuğu olan kişilere ödenecek aylık ödenekler, çocuğun kendi anne ve babasından nafaka gibi gelirleri vardır ${ }^{175}$. Yani veli, çocuk mallarını ve çocuk malllarından doğan gelirleri doğru amaçla, yani çocuğun ihtiyaçları doğrultusunda harcama yetkisi vardır.

\section{d. Çocuğa Terbiye Verme, Çocuğu Eğitme ve Yetiştirme Hakkı}

Veliler çocukların terbiyesini, eğitimini ve iyi şekilde yetişmesini sağlamakla yükümlüdürler ${ }^{176}$. Çocuğa terbiye verilirken, çocuğun şahsına ve

\footnotetext{
170 Крашеников, s.117.

171 Рузакова, s.147; Войтович, s.140.

172 Попова, s.37.

173 Крашеников, s.117.

174 Крашеников, s.117; Попова, s.38.

175 Попова, s.38.

176 Войтович, s.141; Крашеников, s.117.
} 
namusuna saygı ilkesini göz önünde bulundurulmalı ve asla sert ve kaba davranışlarda bulunmamalıdır ${ }^{177}$.

RA m.43/4 ve REK m.19'a göre, her çocuk bedava temel eğitimi almakla yükümlüdür. Veli, çocuğun genel ve meslekî eğitimini nerde ve ne şekilde alacağını seçme hakkına sahiptir ${ }^{178}$. Ancak, seçim yaparken on yaşını dolduran çocuğun isteklerini de göz önünde tutmalıdır ${ }^{179}$.

RAK m.148.1/6'ya göre, velinin, çocuğu yetiştirirken çocuğun da görüşünü ve Velâyet ve Vesayet Kurumunun tavsiyelerini alarak kendi yöntemleri ile yetiştirmeye hakkı vardır. Bu tavsiyeler resmi bir şekilde yazıı veya sözlü olarak verilebilir ${ }^{180}$. Veli, çocuğa terbiye verirken sağlığına bakmak, çocuğun psikolojik, fizikî, ruhanî ve ahlâki gelişmesini sağlamakla yükümlüdür.

\section{e. Çocuğun Kendi Görüşünü Bildirme Hakkı}

RMK m.36/3'e göre, veliler çocukla ilgili işlemleri yaparken çocuğun görüşünü almaları gerekmektedir. Daha önce de belirtildiği gibi on yaşını dolduran ${ }^{181}$ çocuk mahkemede kendi görüşünü bildirmeye hakkı vardır. RAK m.57 gereği, velâyet belirlenirken, çocuğun menfaatine aykırı olmadığı durumlarda, on yaşını doldurmuş çocuğun görüşü dikkate alınması gerekir. RAK m.72/4 uyarınca, velâyet hakkı elinden alınmış anne ve baba çocuğun velâyetini geri istemeleri durumunda, velâyet hakkı geri verilmesi için, on yaşını dolduran çocuğun görüşü dikkate alınacaktır.

\section{f. Çocuğun Adı, Soyadı ve Baba İsmini Alma Hakkı}

RAK m.58/1'e göre, her çocuk adını, soyadını ve baba ismini almaya hakkı vardır. Çocuğun adı anne ve babası tarafından ortaklaşa koyulacaktır. Baba adı olarak çocuğun evrakta babası olarak belirtilen kişinin adı verilecektir. Çocuğun babası belli değilse baba adı olarak annesinin verdiği isim yazılacaktır (RAK m.58/5).

177 Крашеников, s.117; Попова, s.37.

178 Попова, s.3; Войтович, s.141; Крашеников, s.117.

179 Крашеников, s.117.

180 Крашеников, s.117.

181 Rus Aile Kanunu bazı işlemler için belirli yaş sınırlamaları belirlenmiştir. RAK m.57 gereği 59, 72, 132, 134, 136, 143, 145 maddelerinde farklı durumlarda farklı yaş sınırları koyulmuştur. Bu yaş sınırları, çocuğun ayırt etme gücüne sahip olduğu ve kendi tercihini yapmak için uygun görülen yaş sınırları olarak kabul edilmektedir. 
RAK m.58/gereği, anne ve baba evli ise, çocuğa aile soyadı verilecektir. Anne ve babasının soyadlarının farklı olduğu durumlarda ise anne ve babanın anlaşması ile çocuğa ikisinden birinin ya da her ikisinin de soyadı verilecektir $^{182}$. RAK m.58/4 gereği, anne ve baba çocuğun adı ve soyadı ile ilgili ortak karar alamadığı hâllerde Velâyet ve Vesayet Kurumuna başvuru yapmaları gerekmektedir.

\section{g. Anne-baba ve Akrabaları ile Görüşme Hakkı}

RAK m.148.1/5'e göre, çocuğun menfaatine aykırı olmadığı sürece veli çocuğun kendi anne ve babası ile veya akrabaları ile görüşmesine engel koyamaz. Velâyet altındaki çocuğun anne ve babası, ninesi, dedesi, kardeşleri dâhil tüm akrabaları ile görüşmeye hakkı vardır ${ }^{183}$. Çocuk farklı bir ülkede yaşıyorsa bile bu hak yerine getirilmelidir. Çocuğun anne-babası ve akrabaları çocuktan ayrı yaşadıkları durumlarda bile çocuk terbiyesi sırasında katıım sağlamaya hakları vardır. Fakat, çocuğun menfaatine uygun olmaduğı durumlarda anne ve baba ile görüşmek yasaklanabilir ${ }^{184}$.

\section{2. Çocuğun Malvarlığı Bakımından Velâyetin Kapsamı}

\section{a. Çocuğun Mallarının Yönetilmesi}

Rus Hukukunda, çocuk malları ile ilgili temel kural çocuk velinin mallarına, veli de çocuğun mallarına sahip olamaz. Veli ile velâyet altındaki çocuğun malları ayrı olmalıdır. Velâyet altındaki çocuğa ait olan mallar, mallarından gelen gelirler, nafakalar, sosyal yardımlar çocuğun şahsî malvarlığını oluşturur ${ }^{185}$.

RMK m.37'ye göre, velinin velâyet altındaki çocuğun mallarını, mallarından gelen gelirleri yönetmeye hakkı vardır. Veli, çocuğun kendi serbest malları hariç başka mallarını çocuğun menfaatini göz önünde tutarak, Velâyet ve Vesayet Kurumu'nun izni ile yönetir. Nafaka, emeklilik

182 RAK m.58/3 gereği, çocuğun soyadı iki kelimeden fazla olmaması ve soyadı tire ile yazılması gerekir. RAK m.32 göre, eşler evlendiği zaman soyadlarını değiştirmekte özgürdür. İki taraf birbirinin soyadını taşıyabileceği gibi, kendi bekârlık soyadlarında da kalabilirler. Eşler kendi isteği ile bir birinin soyadlarını kendi soyadları ile birlikte de taşyabilirler. Kendi soyadı ile birlikte eşinin soyadını taşyabilmesi için, bekârlık soyadı bir kelimeden fazla olmaması gerekmektedir. Kişinin soyadı en fazla iki kelimeden oluşabilir.

183 Мартынова, s.52; Крашеников, s.117; Попова, s.42.

184 Крашеников, s.118; Попова, s.42.

185 Пулатов, s.36. 
aylığı, yardım ödeneği, sağlığına verilen zarara karşı alınan maddî tazminat için veli ayrı nominal hesap ${ }^{186}$ açar ve Velâyet ve Vesayet Kurumunun iznini almadan harcayabilir. Ancak, nominal hesaptaki paraların harcanması ile ilgili hesap vermek zorundadır ${ }^{187}$. Böylece, kanun koyucu, çocuğun mallarının sadece çocuğa ait olduğunu ve sadece çocuğun ihtiyaçları için harcanması gerektiğini vurgulamıştır.

Veli, velâyet altındaki çocuğun, malları üzerindeki hakkını zedeleyecek herhangi bir işlem yapmaya hakkı yoktur. Örneğin, çocuk mallarını kiraya verme, rehin verme, değiştirme, hediye etme, malları bölme, parçalama veya malları azaltma gibi işlemler yapamaz ${ }^{188}$. Veli, ne velinin eşi veya akrabaları velâyet altındaki çocukla herhangi bir hukukî işlem yapamaz. Ancak, velâyet altındaki çocuğa miras, hediye veya karşııksız kullanmak için malvarlığı verilebilir (RMK m.37/3). Görüldüğg̈ü gibi kanunî düzenlemeler, çocuk mallarının harcanmamasını esas alarak, bunların çoğalmasını sağlamak üzere kaleme alınmıştır.

\section{b. Malların Yönetiminin Güvenceli Kuruma Verilmesi}

RMK m.38/1'e göre, Velâyet ve Vesayet Kurumu gerektiğinde çocuğun mallarının ve kıymetli evraklarının yönetimini sözleşme ${ }^{189}$ ile bir güvenceli kuruma verebilir. Bu durumda, velinin çocuğun güvenceli kuruma verilmeyen mallarını yönetme hakkı devam edecektir.

Çocuk mallarının yönetiminde veli için geçerli olan kurallar güvenceli kurum için de geçerlidir. Güvenceli kurumun çocuk mallarını yönetim hakkı

186 Nominal hesap - bir kişinin adına açılan, ancak hesap sahibinin izni ile ikinci kişilerin de kullanabildiği bir hesap türüdür. Çocuğun bakımı için ödenecek olan sosyal yardımlar, nafaka, emeklilik aylığı veya tazminat gibi gelirler için açılan hesap ta bu hesap türündendir. Nominal hesap açmak için, veli kendi kimliği, velâyeti altındaki çocuğun kimliği ve çocuğun velâyeti kendisine bırakıldığını gösteren belge ile bankaya başvurması yeterlidir (http://www.banki.ru/blog/artm eyskov/6144.php) Erişim tarihi: 28.05.2018.

187 Рузакова, s.147;

188 Пулатов, s.42.

189 RMK m.38 uyarınca, çocuğun mallarının yönetimi sözleşme ile güvenceli kuruma devredebilir. Sözleşme Velâyet ve Vesayet Kurumu ile güvenceli kurum arasında süreli olarak imzalanır. RMK m.37/2 ve m.37/3'te belirtilen çocuk mallarını koruma ile ilgili kurallar, güvenceli kurum için de geçerlidir. 
sözleşme süresinin dolması ile veya velâyetin sona ermesi ile sona erecektir (RMK m.38/2).

\section{3. Çocuğun Temsili Bakımından Velâyetin Kapsamı}

RMK m.32/2'ye göre, veliler velâyet altındakilerin yasal temsilcileridirler ve kanuna uygun olarak onların adına ve menfaatine uygun olarak gerekli işlemleri yaparlar ${ }^{190}$. Velilerin üçüncü kişilere karşı veya mahkemede, velâyeti altındakilerin hak ve menfaatlerini korumak için herhangi bir kurum veya kişiden izin almaları gerekmemektedir (RMK m.31). Çocuğun üçüncü kişilerle yaptığı hukukî işlemler çocuğun zararına yapılmışsa, işlemi geçersiz saymak için velinin itiraz etme hakkı vardır. Veli anne ve babanın sahip olduğu haklara sahip değildir ve çocuğun adını ve ikamet adresini değiştirmeye hakkı yoktur ${ }^{191}$. Çocuğun sebep olduğu durumlardan oluşan maddî veya manevi zararlardan veli sorumludur ${ }^{192}$.

\section{VI. ÇOCUĞUN KORUNMASI VE VELÂYETIN SONA ERMESI}

\section{A. ÇOCUĞUN KORUNMASI}

\section{Türk Hukukuna Göre Çocuğun Korunması}

Kanun koyucu çocuğun korunması için velâyete sahip olan anne ve babaya geniş yetki vermiştir. Bu yetki, anne ve baba tarafından çocuğun menfaatini göz önüne alarak kullanılmalıdır. Vesâyetten farkı olarak velâyette anne ve babayı denetleyen mekanizma kurulmamıştır. Bu nedenle anne veya baba çocuk üzerindeki görevlerini tam ve uygun şekilde yerine getirmeyebilirler ${ }^{193}$. Bu durumlarda, çocuk önemli zarar görebilir. Anne ve babanın velâyet hakkından doğan sorumluluklarını yerine gertirmemesi ya da çocuğa karşı olan yükümlülüklerini savsaklaması durumunda, hâkim çocuğu korumak için gerekli önlemleri alır ${ }^{194}$. Çocuğun korunması için sadece çocuğun şahsına ilişkin değil, malvarlığına da ilişkin gerekli önlemler alınabilir.

\footnotetext{
190 Рузакова, s.147.

191 Крашеников, s.117.

192 Сумбаa, s.24.

193 Kılıçoğlu, Medenî, s.326.

194 Hatemi/ Kalkan Oğuztürk, s. 196; Zeybek, s.64; Dural/ Öğüz/ Gümüş, s.361.
} 


\section{a. Çocuğun Şahsına Illişkin Önlemler}

\section{aa. Genel Olarak}

TMK m.346 uyarınca, çocuğun menfaati ve gelişmesi tehlikeye düştüğü takdirde, anne ve baba duruma çare bulamaz veya buna güçleri yetmezse, hâkim çocuğun korunması için uygun önlemleri alır. Görüldüğü üzere, çocuğun menfaati ve gelişimi tehlikeye düşmesi durumunda gerekli önlemlerin alınması gerektiği kanun koyucu tarafından belirtilmiştir, fakat hangi önlemlerin alınması gerektiği açıkça düzenlenmemiştir. Bu kapsamda, "uygun" önlemlerin alınması için hâkime takdir yetkisi verilmiştir ${ }^{195}$. Koruma önlemlerinin alınabilmesi için, öncelikle çocuğun menfaati ve gelişimi tehlikede olması ve anne ve babanın buna çare bulamamaları veya güçlerinin yetmemesi gibi şartların oluşması gerekmektedir. Çocuğun menfaatinin ve gelişiminin tehlikeye düşmesinde anne ve babanın kusurunun olmaması koruma önlemlerinin alınmayacağı anlamına gelmez. Anne ve babanın kusurlu olup olmaması, ancak alınacak tedbirler açısından etkili olur ${ }^{196}$. Bu kurala uygun olarak anne ve babaya yardımcı olmak için birini görevlendirmek ${ }^{197}$, anne ve babaya belirli yönde davranışta bulunma veya belirli davranştardan kaçınma gibi şartlar koyularak önlemler alınabilir ${ }^{198}$. Hâkim, çocukla anne ve baba arasındaki meseleleri çözmek için, anne ve babaya yol gösterecek eğitimci, psikolog, sosyal hizmet uzmanı, psikiyatrist gibi uzmanların yardımını almaları için de zorlayabilir ${ }^{199}$.

Çocuğun menfaatinin ve gelişiminin tehlikede olduğunu öğrenen herhangi bir ilgili, çocuğu koruma önlemlerinin alınması için başvuruda bulunabilir. Bu ilgililer çocuğun kendisi, komşusu, arkadaşı, öğretmeni, doktor ve başka kişiler de olabilir ${ }^{200}$. Hâkim gerektiğinde re'sen hareket ederek gerekli önlemleri kendisi de alabilir. Çünkü çocuğun korunması doğrudan kamu düzenini ilgilendirmektedir ${ }^{201}$.

\footnotetext{
195 Arat, s.279; Dural/ Öğüz/ Gümüş, s.361.

196 Dural/ Öğüz/ Gümüş, s.361.

197 Zevkliler/ Havutçu, s. 318.

198 Dural/ Öğüz/ Gümüş, s.361.

199 Akyüz, s.279.

200 Arat, s.288-289; Akyüz, s.272-273.

201 Akyüz, s.272-273.
} 


\section{bb. Çocuğun Yerleştirilmesi}

Çocuğu korumaya yönelik olarak hâkim, çocuğu bir ailenin veya bir kurumun yanına yerleştirebilir ${ }^{202}$. TMK m.347'de çocuğu korumaya yönelik olarak çocuğun yerleştirilmesi açıkça düzenlenmiştir. TMK m.347/1'e göre, çocuğun bedensel ve zihinsel gelişmesi tehlike arz eder veya çocuk manen terk edilmiş halde kalırsa, hâkim çocuğu anne ve babadan alarak bir aile yanına veya bir kuruma yerleştirebilir. TMK m.347/2 gereğince, çocuğun aile içinde kalması ailenin huzurunu onlardan katlanmaları beklenemeyecek derecede bozuyorsa ve durumun gereklerine göre başka çare de kalmamışsa, anne ve baba veya çocuğun istemi üzerine çocuk anne ve babadan alınarak bir aile yanına veya bir kuruma yerleştirebilir. Böyle bir karar çocuğun sürekli anne ve baba sözünü dinlememesi, sürekli karşı gelmesi ve itaatsizlik etmesi durumunda alınacaktır ${ }^{203}$.

Çocuğun yerleştirilmesi, çocuğun anne baba yanında kalarak korunması mümkün olmadığı hallerde uygulanan bir önlemdir ${ }^{204}$. Önlemleri uygulamakta anne ve babanın veya çocuğun giderleri ödeyecek durumları yoksa devletçe karşılanır ${ }^{205}$. Kanun koyucu çocuğun kendisinin veya menfaatinin tehlikeye düştüğünde hangi önlemler alınacağı belirtmemiş, "uygun önlem" tâbiri kullanarak bu kararı hâkimin takdir yetkisine bırakmıştır ${ }^{206}$.

\section{b. Çocuğun Mallarına İlişkin Önlemler}

\section{aa. Hâkimin Müdahalesi ve Kontrolü}

Türk Hukukunda çocuğun sadece şahısvarlığı bakımından değil malvarlığı bakımından da çeşitli koruyucu önlemler öngörülmüştür. Böylece, anne ve babanın çocuğun malvarlığına zarar verilmesini önlemektedir.

Anne ve baba çocuğun mallarını yönetmekte ve kullanmakta kendi görevlerini yerine getirmemeleri ve gerekli özeni göstermedikleri

202 Kılıçoğlu, Medenî, s.326; Zeybek, s.67; Elçin, Evgen Gülçin, Türk Medeni Kanunu'nda Soybağı ve Çocuğun Korunmasında Revize Edilmesi Gereken Hükümler, MHB, Yıl 35, S.1, 2015, s.99; Arat, s. 280.

203 Akıntürk/ Ateş Karaman, Aile, s.432.

204 Uyumaz, Çocuğun Korunması, s.1982.

205 Zevkliler/ Havutçu, s. 318; Kılıçoğlu, Medenî, s.326; Hatemi/ Kalkan Oğuztürk, s. 196; Zeybek, s.71.

206 Hatemi/ Kalkan Oğuztürk, s. 196; Zeybek, s.65. 
durumunda gerekli önlemlerin alınması için hâkim müdahale eder, yani uygun önlemleri alır ${ }^{207}$ (TMK m.352/2). Bu hususta, hâkim uyarıda bulunabileceği gibi, emir ve buyruklar da verebilir. Hangi önlemlerin alınması gerektiği tamamen hâkimin takdir yetkisine bağlıdır. Kanun koyucu, anne ve babaya çocuğun mallarını kullanma ve yönetme hakkını vermekle birlikte, onların bu hak ve yükümlülüklerini yeterince yerine getirmeleri ve savsaklamamalarını düzenleyerek, çocuğun mallarının yönetimine de büyük önem verdiği anlaşılmaktadır ${ }^{208}$.

TMK m.360/2'ye göre, hâkim çocuk mallarının yönetimi konusunda belirli zamanlarda verilen bilgi ve hesabı yeterli görmezse malların tevdi edilmesine veya güvence gösterilmesine karar verebilir. Bu güvence aynî ve şahsî, yani rehin veya kefalet şeklinde olabilir ${ }^{209}$.

Çocuk mallarını korumanın bir önlemi mallarla ilgili bazı hukukî işlemlerin geçerliliğinin hâkimin onayına tâbi tutulmasıdır ${ }^{210}$. Çocuk, kendisi ile anne ve babası arasında veya üçüncü kişilerle anne ve babası yararına yapılacak herhangi bir hukukî işlemle borç altına girecek olursa bu işlemin geçerliliği için bir kayyımın katılması veya hâkimin yapılan işlemi onaylaması gerekmektedir ${ }^{211}$.

Bu kural ile kanun çocuğun mallarının korunmasını esas almıştır. Çünkü yapılan hukukî işlem çocuğun yararına olmayıp, ona zarar getirecekse, hâkim işlemi onaylamayacaktır. Yapılmış işlem ise hâkimin onayı olmadan çocuğu bağlamaz, "tek taraflı bağlamazlık" ile geçersiz olur²12.

\section{bb. Yönetimin Kayyıma Devredilmesi}

Yukarıda belirtildiği gibi anne ve babanın çocuğun mallarını yönetmede yeterli özeni göstermemesi durumunda, çocuğun malları tehlikeye düşebilir. Hâkim, takdir yetkisine göre, çocuğun mallarını korumak için uygun önlemler alır. Ancak, çocuk mallarının tehlikeye düşmesi başka yollarla önlenemiyorsa malların yönetimi bir kayyıma devredilir ve böylece

\footnotetext{
207 Şener, s.292; Akıntürk/ Ateş Karaman, Aile, s.432; Zeybek, s.72; Gençcan, s.1713.

208 Akıntürk/ Ateş Karaman, Aile, s.433.

209 Zeybek, s.75; Akıntürk/ Ateş Karaman, Aile, s.433.

210 Zeybek, s.75; Akıntürk/ Ateş Karaman, Aile, s.434.

211 TMK m.345; Akıntürk/ Ateş Karaman, Aile, s.434.

212 Akıntürk/ Ateş Karaman, Aile, s.434; Zeybek, s.76
} 
anne ve babanın çocuk mallarının yönetim hak ve yükümlülükleri kaldııımış olur213.

Bununla birlikte hâkim, çocuk mallarının gelirlerinin veya bu mallardan ayrımış belirli miktarların kanuna uygun şekilde sarfedileceğinden kuşku duyarsa, bunların da yönetimini bir kayyıma bırakabilir.

Çocuk mallarının yönetimini kayyıma devredilmesi çocuk mallarını korumada en ağır önlem sayılır. Kanun koyucu "malların tehlikeye düşmesi başka bir yolla önlenemiyorsa" diyerek çocuk mallarını kayyıma devretmeyi en son çare olarak öngörmüştür ${ }^{214}$. Bu yüzden malların kayyıma devredilmesinden önce hâkim başka önlemleri denemelidir. Hâkim başka uygun önlemlerden sonuç alınamadığı-alamayacağını öngördüğü takdirde kayyıma devretme kararı almalıdır ${ }^{215}$.

\section{Rus Hukukuna Göre Çocuğun Korunması}

Çocuğun anne ve babası veya velisi tarafından velâyeti kötüye kullanılması durumunda korunmaya hakkı vardır ${ }^{216}$. RAK m.56/1'e göre, velâyette çocuğun hak ve menfaatleri Velâyeti ve Vesayet Kurumu ve hâkim tarafından korunmaktadır. Veli tarafından velâyet kötüye kullandığında veya çocuğa şiddet uygulandığında, çocuğun mallarının ve gelirlerinin harcanması durumlarında, çocuğun kendisi veya üçüncü kişiler Velâyet ve Vesayet Kurumuna veya hâkime başvurabilirler. Velinin velâyeti kötüye kullandığı doğrulandığı halde Velâyet ve Vesayet Kurumu çocuğu geçici süreye veliden alabilir veya velâyeti tamamen kaldırabilir ${ }^{217}$.

RAK m.56/2 gereği, her çocuğun anne-baba veya üçüncü kişilerden korunma hakkı vardır. RAK m.56/2 gereği, çocuğun hak ve menfaatlerinin tehlikeye düşmesi, anne ve babanın velâyet görevini gereği gibi yerine getirmemesi, çocuğun terbiye ve eğitimi konusunda yeterli ilgi göstermemesi, çocuğa karşı yükümlülüklerini ağır biçimde savsaklaması, velâyeti kötüye kullanması durumlarında on dört yaşını doldurmayan küçük kendini korumak için Velâyet ve Vesâyet Kurumlarına başvuruda bulunabilir. Fakat, on dört yaşını doldurmayan çocuk mahkemeye başvuru yapamaz.

213 Dural/ Öğüz/ Gümüş, s.363; Zeybek, s.76; Akıntürk/ Ateş Karaman, Aile, s.433.

214 Akıntürk/ Ateş Karaman, Aile, s.434; Zeybek, s.76.

215 Akıntürk/ Ateş Karaman, Aile, s.434.

216 Попова, s.41.

217 Попова, s.41. 
Çocuğun mahkemeye bizzat başvurabilmesi için on dört yaşını doldurmuş olması gerekmektedir.

RAK m.148.1/3'e göre, velinin çocuğa karşı velâyetini kötüye kullandığı durumda, çocuğun kendisi, anne ve babası, akrabaları ve tüm ilgili kişiler Velâyet ve Vesayet Kurumlarına başvurabilirler. Çocuğun hak ve menfaatlerini korumak, Velâyet ve Vesayet kurumu, savcılık ve mahkemenin görevidir ${ }^{218}$. Görüldüğü üzere, kanun koyucu, velâyet altındaki çocuğun hak ve menfaatlerini her bakımdan korumayı sağlamaya çalışmıştır.

\section{B. VELÂYETIN SONA ERMESI}

\section{Türk Hukukuna Göre Velâyetin Sona Ermesi}

\section{a. Anne ve Babanın Ölümü ile}

Anne ve/veya babanın ölmesi sonucu kişiliğin son bulması velâyetin doğal sona erme sebebidir ${ }^{219}$. Eğer anne ve baba evli iken biri ölmüşse velâyet sağ kalana bırakılacaktır220. Anne ve babadan her ikisinin ölümü hâlinde çocuğa bir vasi atanır. Velâyet kişiye sıkı sıkıya bağlı haklardan olduğu için anne baba ölünce velâyet mirasçılara geçmez ${ }^{221}$.

\section{b. Çocuğun Ölümüyle veya Erginliğe Ulaşması ile}

Çocuğun erginliğe ulaşması ile doğal olarak velâyet de sona erecektir ${ }^{222}$. Çocuğun on sekiz yaşını doldurmasıyla normal erginliğe kavuşması velâyetin de sona erdireceği gibi henüz erginliğe kavuşmamış çocukların evlenmesi ve bunun gibi istisnai durumlarda da on sekiz yaşını doldurmamış çocuklar için velâyeti sona erecektir ${ }^{223}$. TMK m.12'ye göre, onbeş yaşını dolduran küçük, kendi isteği ve velisinin rızasıyla mahkemece ergin kılınabilir. TMK m.335/2 gereği, erginliğe kavuşan çocuk kısıtlı ise çocuğa vasi atanmadan çocuk velâyet altında bırakılabilir.

218 Попова, s.42.

219 Ruhi, s.67; Hatemi/ Kalkan Oğuztürk, s. 196; Zeybek, s.79.

220 Serozan, s.254; Hatemi/ Kalkan Oğuztürk, s. 187; Zevkliler/ Havutçu, s.320; Zeybek, s.79; Y. 2.HD, 15.03.2004, E.2004/2344, K.2004/3191 (Oy, Osman, Boşanmanın Hukukî Neticeleri, Nafaka-Tazminat- Velâyet -Mal Paylaşımı ve Aile konutu,1.Bası, İstanbul 2008; s.120).

221 Görgeç, s.29; Zeybek, s.9; Özer Taşkın, s.35; Çetinkaya s.12-13; Karaca, s.8.

222 Hatemi/ Kalkan Oğuztürk, s.196; Zevkliler/ Havutçu, s.319; Zeybek, s.79.

223 Ruhi, s.67; Zevkliler/ Havutçu, s.320; Zeybek, s.79. 
Çocuğun ölümü de velâyeti sona erdiren doğal sebeplerdendir 224 . Çocuğun ölümünden sonra da çocuk anısına saygı göstermek de anne ve babanın yükümlülüğüdür. Çocuğun nereye gömüleceği, organlarını bağışlaması gibi konularda anne ve baba yetkilidir225.

\section{c. Boşanma veya Evliliğin Butlanı}

\section{aa. Genel Olarak}

Boşanma sonucunda velâyetin kime bırakılacağı hususunda hâkime geniş takdir etkisi verilmiştir ${ }^{226}$. Hâkim velâyetin kime verileceği konusunda karar verirken eşlerin mali durumları, boşanmada kusurlu olup olmadıkları ve benzeri durumları dikkate alarak, çocuğun menfaatini doğrultusunda karar vermelidir227.

Boşanma durumunda çocuk kendisine bırakılmayan taraf için velâyet sona ermiş sayılacaktır228. Ancak, boşanma ve ayrılık durumunda çocuk kendisine bırakılmayan taraf gücüne göre, onun bakım ve eğitim giderlerine katılmakla yükümlüdür. Bu giderlere katılma yükümlülüğü iştirak nafakası şeklinde devam eder ${ }^{229}$. Bu hususu hâkim görevi gereği kendiliğinden dikkate alması gerekmektedir ${ }^{230}$. Değişen durumlarda hâkim velâyeti yeniden düzenleyebilir ${ }^{231}$. Örneğin, velâyet kendisine bırakılan tarafın yeniden evlenmesi, bir hastalığa yakalanması gibi.

224 Zevkliler/ Havutçu, s. 320; Zeybek, s.79.

225 Zeybek, s.79.

226 Akyüz, s.233; Uyumaz, Alper, Eski ve Yeni Medeni Kanun Açısından Boşanmanın Kişisel Sonuçları, MÜHFD, 10.Yıl Kuruluş Armağan, 2008/2, s.271-300, s.291.

227 Uyumaz, Boşanma, s.291.

228 Ruhi, s.67; Hatemi/ Kalkan Oğuztürk, s.196; Zeybek, s.80.

229 Akyüz, s.234; Uyumaz, Alper/ Erdoğan, Kemal, Aile Hukukundan Doğan Uyuşmazlıkların Alternatif Çözüm Yolları, DEÜHFD, C.17, S.1, 2015, s.119-169, s.155.

230 Y. 2.HD, 28.03.2005, E.2913/2005, K.4874/2005 (Oy, s.121).

231 Y. 2.HD, 4.04.2002, E.2002/3930, K.2002/4731: "Velâyet kendisine bırakılan tarafa çocuğun karşı taraf ile kişisel ilişkisini engellediği, çocuğun aile bağlarını özellikle fikri gelişmesini kötü etkileyecek bir davranış içerisine girdiği anlaşıldığında, velâyetin değiştirilmesine karar verilmesi gerekir" (http://www.kazanci.com.tr/) Erişim tarihi 05.06.2018. 
Boşanma sonrasında velâyet kendisine bırakılan tarafın ölmesiyle, velâyet kendiliğinden karşı tarafa geçmez, çocuk vesayet altına alınır ${ }^{232}$. Fakat hâkim araştırma yaparak, eğer karşı tarafı velâyete uygun görürse velâyeti karşı tarafa verir veya vasi atar ${ }^{233}$. Bir tarafın ölümüyle velâyet sağ kalan tarafa geçer kuralı sadece ortak kullanmada geçerlidir, boşanma sonrasında ve evliliğinin butlanı hâlinde geçerli değildir ${ }^{234}$.

TMK 336/2'ye göre boşanma hâlinde velâyet mahkeme kararı ile eşlerden birine verilebilir şeklinde düzenlenmiştir. Fakat 6684 sayılı Kanunun ${ }^{235}$ yürürlüğe girmesi ile çocuğun menfaatine uygun olması durumunda, boşanan eşler velâyeti birlikte kullanabilirler ${ }^{236}$. Öğretide ve Yargıtayda bazı görüşler ${ }^{237}$, boşanmadan sonra ortak velâyetin çocuğun menfaatine aykırı olduğunu ve velâyetin yalnızca anne veya babadan birine verilmesi gerektiğini savunmaktadır ${ }^{238}$. Diğer bir görüş ise, boşanma hâlinde anne ve babanın velâyeti ortak kullanmaları çocuğun menfaatine uygun olduğunu savunmaktadır ${ }^{239}$.

Evliliğin butlanına karar verilen durumlarda, TMK m.157/2 gereği, boşanmaya ilişkin hükümler kıyas yoluyla uygulanacaktır. Hâkim anne ve babayı dinleyecek, çocuk vesayet altında ise vesayet makamının düşüncesini

232 Y. 2.HD, 19.09.2005, E.2005/10209, K.2005/12282 (http://www.kazanci.com.tr/) Erişim tarihi 05.06.2018; Uyumaz, Boşanma, s.293.

233 Y. 2.HD, 10.05.2004, E.2004/5256, K.2004/6056 (http://www.kazanci.com.tr/) Erişim tarihi 05.06.2018.

234 Hatemi/ Kalkan Oğuztürk, s.187; Zeybek, s.80.

235 RG. 25.03.2016-29664.

236 Ortak velâyet başlığında daha ayrıntılı bilgi verilmiştir. Bkz. Vı başlık, B/1/c/bb.

237 Bununla ilgili Yargıtay bir kararında şöyle demektedir: "Evlilik devam ettiği sürece anne ve baba velâyeti birlikte kullanırlar, boşanma ve ayrılığa karar verilmesi hâlinde hâkim velâyeti eşlerden birine vermek zorundadır. Velâyetin düzenlenmesi kamu düzeni ile ilgili olup, yabancı mahkemenin ortak çocuğun velâyetini anne ve babanın her ikisi üzerinde bırakan kararı Türk Medeni Kanunu'na aykırıdır. Bu sebeple yerel mahkemenin velâyetin tenfizi kararını reddi isabetlidir" Y. 2.HD, 15.04.2003, E.2003/4019, K.2003/5500 (Çetinkaya, s. 55).

238 Görgeç, s.23; Zeybek, s.10.

239 Akyüz'e göre boşanan anne baba arasındaki tartışmaları ya çocuk üzerinde sürdürecekler ya da velâyete sahip olmayan taraf çocuğun yaşamından ve sorumluluklarından kısmen veya tamamen uzaklaşacaktır. Bkz., Akyüz, s.237. 
dinleyerek, anne ve baba ve çocuk arasındaki ilişkileri düzenleyecektir ${ }^{240}$. Evliliğin butlanı hâlinde velâyet bir taraf için veya her iki taraf için de mahkeme kararı ile sona erebilir ${ }^{241}$.

Evliliğin butlanı durumunda hâkim velâyetin hangi tarafa bırakılacağına karar verirken çocuğun menfaati doğrultusunda hareket etmelidir. Türk Hukuku boşanma veya evliliğin butlanı durumunda velâyetin kusursuz tarafa verilmesi gerektiği yönünde bir görüş benimsemiş değildir. Çünkü butlan, sebepleri bakımından kötüniyetli eşin aynı zamanda kötü bir anne veya kötü bir baba olduğu anlamına gelmez. Velâyet atanırken eşlerin maddi durumları da çocuğun menfaatinden üstün tutulamaz. Çocuğun menfaati her zaman ön planda tutulması gerekmektedir. Evlenmenin butlanı durumunda velâyetin kime bırakılması konusunda çocuğun yaşı, cinsiyeti, karakteri, anne ve babadan her birinin oturduğu yer ve çevre gibi hususlar göz önünde bulundurulmalıdır. Bununla birlikte, çocuğun kendi istekleri de nazara alınması gerekir. Fakat, bunun için çocuğun ileri yaşta olması ve kimsenin baskısı altında olmadığına kanaat getirilmelidir ${ }^{242}$.

\section{bb. Ortak Velâyet}

TMK m.182/1 gereği boşanma durumunda mahkeme anne ve babanın haklarını ve çocuk ile olan kişisel ilişkilerini düzenler. TMK m.336/2'ye göre ortak hayata son verilmiş veya ayrılık hâli gerçekleşmişse hâkim, velâyeti eşlerden birine verebilir. Fakat 6684 sayılı Kanunun yürürlüğe girmesi ile çocuğun menfaatine uygun olması durumunda, boşanan eşler velâyeti birlikte kullanabilirler. Yani, artık velâyetin anne ve babadan birisine ya da her ikisine verilmesi hâkimin takdir yetkisine bırakılmıştır243.

6684 sayılı Kanunu ile "11 No'lu Protokol ile Değişik İnsan Haklarını ve Ana Hürriyetleri Korumaya Dair Sözleşme'ye Ek 7 No'lu Protokol"ü yürülüğe girmiştir. Bu Protokol Türkiye'de de ortak velâyete yol açmıştır. Ek 7 No'lu Protokol"ün m.5'inci hükmüne göre, eşler evliliğin sona ermesi durumunda,

\footnotetext{
240 Hatemi/ Kalkan Oğuztürk, s.187.

241 Zeybek, s.80.

242 Akkurt, Sinan Sami: Türk Medenî Hukukunda Evlenmenin Butlanı, Konya 2015, s.193-194.
}

243 Akyüz, s.233. 
çocukları ile ilişkilerinde medeni haklar ve sorumluluklardan eşit şekilde yararlanırlar ${ }^{244}$.

Türk Anayasa'sına 07.05.2004 tarihinde birtakım değişiklikler yapılmıştır. Bu değişiklikler ile 90.maddenin son fıkrasına "Usulüne uygun yürürlüğe konulmuş temel hak ve özgürlüklere ilişkin milletlerarası andlaşmalarla kanunların aynı konuda farklı hükümler içermesi nedeniyle çıkabilecek uyuşmazlıklarda milletlerarası andlaşma hükümleri esas alınır" cümlesi eklenmiştir. Böylece, uluslararası andlaşmaların iç kanundan önce uygulandığı açıkça düzenlenmiştii ${ }^{245}$. Dolayısıyla, mevcut sistemin tamamen değiştiğini ve çocuk menfaatine aykırı olmadığı durumlarda velâyetin anne ve babaya ortak verilmesi mümkün olduğu anlaşılmaktadır.

\section{d. Evlatlık Ilişkisi ve Soybağının Reddi ile}

Çocuğu, üçüncü kişi evlat edinirse, anne ve babanın evlatlık ilişkisi sona ermesiyle velâyet ilişkisi de sona erecektir ${ }^{246}$. TMK m.286 gereği, soybağı reddine karar verilmesi durumunda, babalık karinesi çürütülmüş olduğundan, velâyete sahip babanın velâyeti de sona erecektir. Bu durumda velâyet tek başına anneye ait olur veya çocuğa vasi atanır ${ }^{247}$. Çocuğun anaya bağlı soybağında herhangi bir değişiklik oluşmaz. Çocukla babanın arasında soybağı sona erdiği durumlarda, çocuk artık babaya mirasçı olamaz, onun soyadını taşıyamaz ve doğumla kazandığı vatandışığı kaybeder. Soybağının

244 Aynı yönde bkz. "....Türkiye Cumhuriyeti adına 14 Mart 1985 tarihinde imzalanan "11 Nolu Protokol ile Değişik İnsan Haklarını ve Anne Hürriyetleri Korumaya Dair Sözleşmeye Ek 7 Nolu Protokol", 6684 sayılı Kanun ile onaylanması uygun bulunarak, 25.03.2016 tarihli Resmi Gazete'de yayınlanıp yürürlüğe girmiş ve iç hukukumuz hâlinde almıştır. Ek 7 Nolu Protokol'ün 5. maddesine göre, "Eşler, evlilik bakımından, evlilik süresince ve evliliğin bitmesi hâlinde, kendi aralarındaki ve çocuklarıyla olan ilişkilerinde, özel hukuk niteliği taşıyan hak ve sorumluluklar açısından eşittir. Bu madde, devletlerin çocuklar yararına gereken tedbirleri almalarına engel değildir". "Ortak Velâyet" düzenlenmesinin, Türk Kamu düzenine "açıkça" aykırı olduğunu ya da türk toplumunun temel yapısı ve temel çıkarlarını ihlal ettiğini söylemek mümkün değildir...... Y. 2.HD, 20.02.2017, E.2016/15771, K.2017/1737 https://www.kararara.com/forum/viewtopic.php?f=47\&t=3795 (Erişim tarihi: 20.02.2018).

245 Belgin, Derya, Anayasa'nın 90. Maddesinde (7 Mayıs 2004) Yapılan Değişikliğin Getirdiği Sorunlar ve Çözüm Önerileri, ABD, S.4, 2008, 110-113, s.110.

246 Akyüz, s.240;

247 Zeybek, s.81. 
hükmü ile babasız kalan çocuk, kendi babası tarafınfan tanınabilir, bu mümkün değilse, babalık davası açabilir ${ }^{248}$.

\section{e. Gaiplik ile}

TMK m.32'ye göre, ölüm tehlikesi içinde kaybolan veya kendisinden uzun zamandan beri haber alınmayan bir kimsenin ölümü hakkında kuvvetli olasılık varsa gaipliğe karar verilebilir. Eşlerden birinin gaipliğine karar verilirse velâyet sağ kalan tarafa ait olur ${ }^{249}$.

TMK m.35/1'e göre, ilandan sonuç alınamazsa, mahkeme gaipliğe karar verir ve ölüme bağlı haklar, aynen gaibin ölümü ispatlanmış gibi kullanıır. Gaiplik ölüm gibi değerlendirilse de hakkında karar verilen tarafın velâyet hakkının kaldırılıp kaldırılmayacağı tartışmalı bir konudur. Bir görüşe göre, gaiplik kararı verildikten sonra velâyet sağ olan tarafa kendiliğinden geçmelidir ${ }^{250}$. Diğer bir görüşe göre, gaiplik kararından sonra evlilik feshedilene kadar gaip olan kişinin velâyeti devam eder ${ }^{251}$. İinci görüş daha tutarlıdır. Hakkında gaiplik kararı verilen tarafın velâyeti kullanma yetkisi azalacak ve dolayısı ile sağ kalan eş velâyetle ilgili kararları kendisi alacaktır.

Velâyet altında bulunan çocuk hakkında gaiplik kararı verilirse velâyet kendiliğinden sona erer. TMK m.351'e göre, gaiplik hâli sona ermişse velâyetin iadesi için dava açıı ır252.

\section{f. Mahkeme Kararı ile}

\section{aa. Genel Olarak}

Anne babanın çocuk üzerindeki velâyeti çocuk ergin olana kadar devam eder. Ancak, hâkim bazı durumlarda anne ve babanın velâyeti kötüye kullanmalarından dolayı çocuğu korumaya yönelik gerekli önlemleri alabilir. Örneğin, velâyet anne ve babadan alınabilir ${ }^{253}$.

Çocuğun korunması için diğer önlemlerden sonuç alınmazsa ya da bu önlemlerin yetersiz olacağı önceden anlaşlırsa hâkim kararı ile velâyet

\footnotetext{
248 Akyüz, s.150.

249 Hatemi/ Kalkan Oğuztürk, s.187; Öztan, Bilge, Medeni Hukuk'un Temel Kavramları, Ankara 2014, s.506.

250 Zeybek, s.81; Birinci, s.145.

251 Zeybek, s.81.

252 Zeybek, s.81.

253 Hatemi/ Kalkan Oğuztürk, s.196; Helvacı/ Erlüle, s.197; Zeybek, s.82.
} 
kaldırııı (TMK m.348). Velâyetin kaldırılması en ağır bir önlemdir ${ }^{254}$. Velâyetin kaldırılmasına neden olan sebepler, Türk Medeni Kanunu'nun Altıncı Ayırımında düzenlenmiştir. Kanunda düzenlenen bu sebepler olmadıkça velâyet kaldırılamaz ${ }^{255}$. Anne ve babanın birinden velâyet alınırsa diğeri velâyeti sürdürür. Velâyet anne ve babanın her ikisinden de alınabilir. Bu durumda çocuğa vasi atanır ${ }^{256}$. Kararda aksi belirtmedikçe, velâyetin kaldırılması mevcut ve doğacak olan çocukların hepsini kapsar (TMK m.348). Velâyetle ilişkin kararları aile mahkemesi verecektir ${ }^{257}$. HMK m.382/1 b.13 göre, velâyetin kaldırılması, çekişmesiz yargı işlerindendir. HMK 384 gereği, "Kanunda aksine hüküm bulunmadıkça, çekişmesiz yargı işleri için talepte bulunan kişinin veya ilgililerden biririnin oturduğu yer mahkemesi yetkilidir." Kanunda aksine bir hüküm bulunmadığı için, velâyetin kaldırılmasında yetkili mahkeme, velâyeti kendine almak isteyen tarafın yerleşim yeri olabileceği gibi ilgili çocuğun yerleşim yeri de olabilir. Çocuk anne babadan ayrı yaşaması durumunda, yetkili mahkeme, çocuğun yerleşim yeri veya oturduğu yer de olabilir ${ }^{258}$.

\section{bb. Velâyetin Kaldırılmasının Şartları}

\section{aaa. Velâyet Görevinin Gereği Gibi Yerine Getirilmemesi}

Anne ve baba görevlerini gereği gibi yerine getirememeleri durumunda velâyet kaldırılır. Velâyet görevini gereği gibi yerine getirmelerini önleyen sebepler arasında anne ve babanın deneyimsizliği, hastalığı, engelli olmaları, başka yerde bulunmaları gibi durumlar olabilir ${ }^{259}$.

Kanun koyucu velâyetin kaldırma şartlarını TMK m.348 sayılı sebeplerle sınırlamamıştır. "Buna Benzer Sebepler" ifadesini kullanarak bu durumlara benzer sebeplerden dolayı da velâyetin kaldırılabileceğini

254 Akıntürk/ Ateş Karaman, Aile s.438; Zeybek, s.82; Akıntürk/ Ateş Karaman, Medeni, s.303.

255 Arat, s.280; Akıntürk/ Ateş Karaman, Aile s.438.

256 Zeytin/ Ergün, s.212; Zevkliler/ Havutçu, s.320; Helvacı/ Erlüle, s.198; Akıntürk/ Ateş Karaman, Aile s.438; Gökçe, s.62.

257 Tutumlu, s.1382; Akıntürk/ Ateş Karaman, Aile s.438; Uyumaz, Çocuğun Korunması, s.1996; Zeybek, s.83.

258 Uyumaz, Çocuğun Korunması, s.1996.

259 Kılıçoğlu, Medenî, s.327; Arpacı, s. 377; Akıntürk/ Ateş Karaman, Aile, s.438; Zeytin/ Ergün, s.212; Helvacı/ Erlüle, s.198; Hatemi/ Kalkan Oğuztürk, s. 197; Akıntürk/ Ateş Karaman, Medeni, s.303. 
öngörmüştür ${ }^{260}$. Hâkimin velâyetin kaldırılmasına karar vermesi için TMK m.348'de sayılan hallerin süreklilik taşıması gerekmektedir ${ }^{261}$.

\section{bbb. Anne ve Babanın Illgisizliği ve İhmâlkârlığı}

Anne ve babanın çocuğa yeterli ilgiyi göstermemesi veya ona karşı yükümlülüklerini ağır biçimde savsaklaması, ona karşı ihmâlkâr davranmaları velâyetin kaldırılmasının en önemli sebeplerindendir ${ }^{262}$. Anne ve babanın çocukla hiç ilgilenmeyerek, onun sokaklarda boş boş dolanmasına ve kötü alışkanlıklar edinmesine sebep olmaları, hastalanan çocuğa gerekli tedaviyi sağlamayarak kadere terk etmeleri, düzenli okuyan çocuğu okula göndermeyerek çalıştırmaları veya bir sanatkârın yanında çırak olarak çalıştırmaları ve bunun gibi durumlar velâyetin kaldırılma sebeplerindendir ${ }^{263}$.

\section{ccc. Anne ve Babanın Yeniden Evlenmesi}

Velâyet, anne ve babadan birinin ölümü, boşanma, evliliğin feshi veya butlan dolayısıyla ortadan kalktığı zaman, sağ kalan tarafa veya anne ve babadan birisine bırakılır. Bu durumlarda, anne veya babadan birisi velâyeti tek başına kullanır. TMK m.349'a göre, velâyet kendisine bırakılan tarafın yeniden evlenmesi velâyetin kaldırımasını gerektirmez. Ancak, anne ve babanın yeniden evlenmesi çocuk için oldukça tehlikeli bir durumdur. Çünkü üvey anne veya üvey babanın çocuğa inmâlkâr davranmaları yüksek olasılıktır ${ }^{264}$. Bu nedenle, kanun koyucu, bu tehlikeyi dikkate alarak anne ve babanın yeniden evlenmesi durumunda, çocuğun menfaati için velâyet sahibini resen değiştirilebileceği gibi, durum ve koşullara göre, talep üzerine velâyeti kaldırılarak çocuğa vasi de atanabilir ${ }^{265}$.

260 Dural/ Öğüz/ Gümüş, s.364; Akıntürk/ Ateş Karaman, Aile, s.438; Uyumaz, Çocuğun Korunması, s.1990.

261 Arat, s.281.

262 Zeytin/ Ergün, s.212; Akıntürk/ Ateş Karaman, Aile s.438; Helvacı/ Erlüle, s.198; Gökçe, s.62; Kılıçoğlu, Medenî, s.327; Hatemi/ Kalkan Oğuztürk, s. 197; Akıntürk/ Ateş Karaman, Medeni, s.303.

263 Akyüz, s.301.

264 Çelik, s.279; Akıntürk/ Ateş Karaman, Aile, s.438; Kılıçoğlu, Yenilikler, s.136.

265 Hatemi/ Kalkan Oğuztürk, s. 197; Gökçe, s.62; Akıntürk/ Ateş Karaman, Aile, s.438;

Zeytin/ Ergün, s.212; Arat, s.293. 


\section{g. Velâyetle Illgili Uyuşmazlıkların Arabuluculuğa Elverişliliği Sorunu}

22.06.2012 tarihinde yürürlüğe giren 6325 sayılı Hukuk Uyuşmazlıklarında Arabuluculuk Kanunu'nun 1 inci maddesinde hangi konuların arabuluculuğa elverişli olduğu düzenlenmiştir. HUAK m.1/2'ye göre, bu kanun, tarafların üzerinde serbestçe tasarruf edebilecekleri iş veya işlemlerden doğan özel hukuk uyuşmazlıklarının çözümlenmesinde uygulanır.

Boşanma sonucunda velâyetle ilişkin birtakım uyuşmazlıklar ortaya çıkabilir. Bunlar: velâyetin hangi tarafa verileceği, iştirak nafakası, velâyet kendisine bırakılmayan tarafın çocukla kişisel ilişki kuramaması ${ }^{266}$. TMK m.182 gereği, boşanma veya ayrılık sonucunda çocuk ile anne ve baba arasındaki kişisel ilişkileri hâkim düzenler. Hâkim, velâyetin hangi tarafa bırakılacağı konusunda, çocuğun yüksek yararı ilkesini göz önünde tutarak, çocuğun menfaatine uygun karar verir ${ }^{267}$. TMK m.326 gereği velâyet kendisine bırakılmayan taraf çocukla ilişki kurabilmesi için mahkeme kararı verilmesi gerekir. Bu konuda taraflar anlaşma yapabilirler, ancak, anlaşmayı hâkim onaylamadığı sürece anlaşma geçerli olmaz. Velâyet kendisine bırakılmayan tarafın çocuğun bakım ve yetiştirilmesi için gerekli giderlerine, yani iştirak nafakasına hükmedilmesi için tarafların istemde bulunması aranmamaktadır. Taraflar istemde bulunmasa da hâkim iştirak nafakasına hükmedecektir ${ }^{268}$.

Görüldüğü üzere, velâyet ilişkisi, aile hukukunda devletin doğrudan müdahale ettiği en yoğun ilişkidir. Velâyetle ilişkin her türlü işlemlerde çocuğun yüksek yararı ve korunması mutlak bir amaçtır. Çocuk kendini koruyamaz ve anne ve baba anlaşarak çocuğa zarar vermeleri mümkündür. Bu nedenle, velâyet tarafların üzerinde serbestçe tasarruf edebilecekleri bir husus değildir ve velâyetle ilişkin uyuşmazlıklar arabuluculuğa elverişli olması mümkün değildir ${ }^{269}$.

\section{h. Velâyetin Sona Ermesinin Sonuçları}

Velâyet anne ve babanın birisinden alınırsa velâyet hakkı tek başına bir tarafa ait olur. Velâyet anne ve babanın her ikisinden kaldırılınca çocuğa vasi

\footnotetext{
266 Demiroğlu, Huriye, Rayhan, s. 59.

267 Akyüz, s.233.

268 Uyumaz/ Erdoğan, s.156; Akkurt, Kitap, s.204.

269 Uyumaz/ Erdoğan, s.157; Demiroğlu, Huriye, Rayhan, s. 76.
} 
atanır $^{270}$. Çocuk vesayet altına alınmış ve vesayete ilişkin hükümlere tâbi olur.

Velâyetin kaldırılması sadece çocukların şahısvarlığı ile ilgili değil, mallarıyla ilgili de sonuçlar doğurur. Velâyet kaldırılınca anne ve baba çocuğun malları üzerindeki yönetim hakkını ve bazen de kullanma haklarını kaybederler ${ }^{271}$. Velâyet, anne ve babanın kendi kusurlarından değil, yaşlılık veya hastalık gibi kusursuz olma sebebiyle kaldırılmışsa çocuk ergin olana kadar çocuğun mallarını kullanma hakları vardır272.

Velâyet kaldırımışsa bile anne ve baba çocuğun bakım, eğitim ve yetiştirilmesi için gerekli masrafları karşılamak zorundadırlar ${ }^{273}$. Anne ve babadan veya çocuk mallarından bu giderler karşılanmıyorsa, bu masraflar devlet tarafından karşılanır ${ }^{274}$. TMK m.438 gereği velâyetin kaldırılması hakkındaki kararda aksi belirtilmedikçe hüküm mevcut ve ileride doğacak olan tüm çocukları kapsar.

\section{i. Durumun Değişmesi}

Velâyet hakkı kaldırıldıktan sonra hayatın doğal akışında farklı değişiklikler oluşabilir. Durumun değişmesi hâlinde çocuğun korunmasına ilişkin önlemlerin yeni şartlara uygun olarak uydurulması gerekir ${ }^{275}$. Böyle durumda, çocuk hakkında koruma önlemleri kaldırılır veya değiştirilir. TMK m.348 gereği Velâyetin kaldırılmasını gerektiren sebepler ortadan kalktığında, hâkim kendiliğinden veya anne ve babanın istekleri üzerine velâyeti anne ve babaya geri verebilir ${ }^{276}$.

270 Zevkliler/ Havutçu, s. 320; Akıntürk/ Ateş Karaman, Aile, s.441; Çökçe, s.62; Hatemi/ Kalkan Oğuztürk, s. 197.

271 Akıntürk/ Ateş Karaman, Medeni, s.303.

272 Arat, s.292; Zeybek, s.94; Akıntürk/ Ateş Karaman, Aile, s.441.

273 Hatemi/ Kalkan Oğuztürk, s. 197; Zeytin/ Ergün, s.212; Akıntürk/ Ateş Karaman, Aile, s.441; Akıntürk/ Ateş Karaman, Medeni, s.303.

274 Zeytin/ Ergün, s.212; Akıntürk/ Ateş Karaman, Aile, s.441; Hatemi/ Kalkan Oğuztürk, s. 197.

275 Akıntürk/ Ateş Karaman, Aile, s.441; Zeytin/ Ergün, s.212; Kılıçoğlu, Medenî, s.327; Hatemi/ Kalkan Oğuztürk, s. 198.

276 Kılıçoğlu, Medenî, s.327; Hatemi/ Kalkan Oğuztürk, s. 198; Zeytin/ Ergün, s.212;

Akıntürk/ Ateş Karaman, Aile, s.441; Helvacı/ Erlüle, s.198; Öztan, s.511. 


\section{Rus Hukukuna Göre Velâyetin Sona Ermesi}

\section{a. Çocuğun On Dört Yaşını Doldurması}

Rus hukukunda genel olarak, çocuğun ayırt etme gücü ve psikolojik durumlarına göre farklı yaş sınırları belirlenmiştir. RAK m.145/2 gereği, on dört yaşına kadar velâyet altında, on dört yaştan on sekiz yaşına kadar vesayet altında olur. Yaş sınırının böyle belirlenme sebebi, on dört yaşına kadar çocuğun sınırlı ehliyetsiz olmasındandır. Çocuğun adına tüm işlemleri veli yapar. Vesayette ise, çocuk ayırt etme gücüne sahip ve kendi başına karar alabilecek yaşta olduğu için, vasi çocuğa işlemler yapmasında izin verir ve gerekli durumlarda akıl verir. Çocuğun on dört yaşını doldurması ile velâyet kendiliğinden sona erecektir ${ }^{277}$. Veli ise hiçbir karara gerek olmadan çocuğun vasiliğine devam edecektir ${ }^{278}$.

b. Çocuğun Kendi Anne ve Babasına Geri Verilmesi veya Evlat Edinilmesi

Velâyet altına alınan çocuğun kendi anne ve babası, velâyet hakkının sonra ermesine sebep olan hususları ortadan kaldırarak, küçüğü veliden geri isteyebilirler. Bunun gibi, velâyet altında bulunan çocuğu üçüncü kişiler evlat edinebilirler. Küçüğün kendi anne ve babasına geri verilmesi veya başka birisi tarafından evlat edinilmesi durumunda velâyet sona erecektir ${ }^{279}$. Velâyet altındaki çocuğun anne ve babası çocuğu geri istemeleri durumunda, veli geri verilmesini uygun görürse, çocuk anne ve babaya verilecektir. Ancak, velinin çocuğu geri vermek istemediği durumlarda Velâyet ve Vesayet Kurumuna veya mahkemeye başvurulur. Çocuk veli tarafından evlat edinebilir veya başka birisine evlatlık verilebilir. Çocuğu, başka birine evlatık vermek için velinin rızası alınmalıdır. Velinin rızası yoksa Velâyet ve Vesayet Kurumuna veya mahkemeye başvurulması gerekmektedir ${ }^{280}$. Çocuğa veli atandığı andan itibaren çocuğun anne ve babasının veya önceki velisinin velâyetten doğan hak ve yükümlülükleri sona erecektir (RAK m.148.1/2).

\section{c. Çocuğun Kuruma Yerleştirilmesi}

Çocuğun menfaatine aykırı olmaması şartı ile çocuğu eğitim kurumuna, sağlık kurumuna, çocuk esirgeme kurumuna, sosyal yardım veren

\footnotetext{
277 Низамиева, s.103.

278 Низамиева, S.103.

279 Рузакова, s.148; Гомола А.И./ Гомола И.А., s.134.

280 RMK m.39/1; Попова, s.61.
} 
kurum veya kuruluşlara yerleştirilmesi mümkündür ve böyle durumlarda velâyet sona erecektir ${ }^{281}$.

\section{d. Velinin Kendi İsteği ile Velâyetin Sona Ermesi}

Veli kendi isteği ile velâyetten doğan hak ve görevlerinden vazgeçtiği durumlarda velâyet sona erecektir. Velâyet velinin isteği üzerine verilir ve maddî bir karşllığı yoktur. Bu nedenle velâyetten vazgeçmek velinin hakkıdır ${ }^{282}$.

\section{e. Erginliğe Erişmiş Çocuğun Fiili Ehliyetini Kazanması}

RMK m.40/1'e gereği, velinin veya Velâyet ve Vesayet Kurumu'nun başvurusu üzerine, mahkeme kararı ile erginliğe erişmiş çocuğun kısıtlılığı kaldırılabilir. Çocuk, mahkeme kararı ile fiili ehliyetini kazandığı durumlarda, velâyet sona erecektir.

\section{f. Çocuğun veya Velinin Ölümü ile Velâyetin Sona Ermesi}

RVVFK m.29/1'e göre, velâyet altındaki çocuğun veya velâyete sahip velinin ölümü ile velâyet sona erecektir ${ }^{283}$. Çocuğun veya velinin ölümü velâyetin sona ermesinin doğal sebeplerinden biridir. Bununla birlikte, velinin veya çocuğun gaipliği, velinin ehliyet kaybı durumunda velâyet sona erecektir ${ }^{284}$.

\section{g. Velâyetin Mahkeme Kararı ile Kaldırılması}

\section{aa. Velâyet Görevinin Gereği Gibi Yerine Getirilmemesi}

Velinin, üzerindeki görevlerini gereği gibi yerine getirmemesi, görevini kötüye kullanması, küçüğü gözetimsiz bırakması veya gerekli yardımları yapmaması durumlarında, Velâyet ve Vesayet Kurumu velâyeti kaldırabilir285. Velâyet kaldırıldıktan sonra gerekli soruşturma başlatılması için gerekli işlemler yapılır. Velâyeti gereği gibi yerine getirmemesi sebebinden dolayı velâyetin kaldırılması, veli için herhangi bir kötü sonucu yoktur. Ancak, velinin, velâyeti kötüye kullandığı veya çocuğun hak ve menfaatlerine zarar

\footnotetext{
281 RMK m.39/1; Попова, s.61; Рузакова, s.149; Гомола А.И./ Гомола И.А., s.140.

282 Войтович, s.142; Рузакова, s.149; Попова, s.61.

283 Сумбаа, s.25; Попова, s.55; Войтович, s.142.

284 Пулатов, s.72.

285 Войтович, s.142; Сумбаa, s.26; Попова, s.60; Гомола А.И./ Гомола И.А., s.140.
} 
verdiği tespit edilirse, bilgiler savcılığa iletilecek ve veli hakkında soruşturma başlatılacaktır 286

\section{bb. Veli ve Çocuk Menfaatlerinin Çatışması}

RMK m.39/2'ye göre, velinin ve küçüğün menfaatleri çatıştığı durumlarda, Velâyet ve Vesayet Kurumu velâyet hakkını geçici bir süreye durdurabilir veya tamamen kaldırmaya yetkilidir ${ }^{287}$. Geçici süreyle velâyet hakkı durdurulduğu zaman, çocuk Velâyet ve Vesayet kurumunun yerleştrdiği kurumlarda kalacaktır. Veli ile çocuğun menfaatlerinin çatıştığı durum ortadan kalktığı zaman, çocuğun velâyeti veliye geri verilecektir ${ }^{288}$.

\section{GENEL KARŞILAŞTIRMA}

Türk ve Rus Hukukunda velâyetin asıl amacı çocuğun hak ve menfaatlerinin korunması ve çocuğun temsil edilmesidir. Her iki hukukun kuralları kültür, din ve ülke durumuna göre farklılık gösterse de, iki hukuk sisteminde de çocuğun yüksek yararı ve korunması ön plandadır.

Türk Hukukunda Velâyet ile ilgili kurallar 4721 sayılı Türk Medeni Kanunu'nun m.335-363 düzenlenmiştir. Rus Hukukunda velâyet hükümleri, Rus Medeni Kanunu'nda m.31-40 arası, Rus Aile Kanunu'nda m.145-148.1 arasında ve ayrıca Rus Velâyet ve Vesayet Federal Kanunu'nda da düzenlenmiştir. Rus Hukuku'nda velâyetin tanımı ve hukukî nitelikleri Türk Hukukundan farklıdır. Türk Hukukunda velâyet hakkı, sadece anne ve babaya aittır. Rus Hukukunda ise, erginliğe erişmiş, fiili ehliyeti olan herhangi bir kişi velâyete sahip olabilir. TMK m.335'e göre, ergin olmayan çocuklar, yani on sekiz yaşından küçük çocuklar velâyete tâbidirler. Rus hukukunda ise anne ve babası veya evlat edineni olmayanlar, anne ve babasından velâyet kaldırılmış ve anne ve baba gözetimi dışında kalan, 14 yaşını doldurmamış çocuklar velâyete tâbidirler.

Türk ve Rus Hukukunda velâyetin kullanımı ve kapsamı benzerlik göstermektedir. Çocuğun adı ve soyadını koymak, eğitimi ve yerleşim yerini belirlemek, çocuğu temsil etmek, mallarını yönetmek velâyetin kapsamındadır. Velâyetin kötüye kullanılması tespit edildiğinde, hâkim çocuğun şahısvarlığı ve malvarlığını korumak için gerekli önlemleri alır. Bu önlemler sonuç vermediği durumlarda velâyetin kaldırılması söz konusu olur.

\footnotetext{
286 Попова, s.60; Гомола А.И./ Гомола И.А., s.140.

287 Рузакова, s.149; Войтович, s.142.

288 Войтович, s.145.
} 
Her iki hukuk sisteminde de çocuğun menfaatinin ve gelişiminin tehlikede olduğunu öğrenen herhangi bir ilgili, çocuğu koruma önlemlerinin alınması için mahkemeye başvuruda bulunabilir. Bu ilgililer çocuğun kendisi, yakın çevresi ve başka kişiler de olabilir. Rus Hukukunda on dört yaşını doldurmayan küçük, kendini korumak için Velâyet ve Vesâyet Kurumlarına başvuruda bulunabilir. On dört yaşını doldurmuş çocuklar ise mahkemeye başvuru yapabilirler. Türk Hukukuna göre velâyet başkasına devredilemez, mirasçılara geçmez, çocuğun rızası olsa dahi kısmen veya tamamen bu haktan feragat edilemez ${ }^{289}$. Rus Hukukunda ise veli kendi isteği ile velâyetten doğan hak ve görevlerinden vazgeçebilir, vazgeçtiği takdirde ise velâyet sona erecektir ${ }^{290}$.

\section{SONUÇ}

Türk Hukukuna göre, velâyet küçüklerin ve istisnaî durumlarda ergin kısıtıların şahıs varlıklarının korunması, bakımı, geliştirilmesi, yetiştirilmesi, mallarına özen gösterilmesi ve korunması, aynı zamanda onların temsil edilmesi konularında kanun koyucunun anne ve babaya verdiği yetki ve haktır. Velâyet hakkı iki yolla kazanılmaktadır. Bunlar: çocuğun doğumu ve mahkeme kararından oluşur. Evlilik içinde doğan çocuk velâyeti anne ve baba tarafından birlikte kullanıımaktadır. Buna karşın, evlilik dışı doğan çocuk velâyeti yalnızca anneye aittır. Daha sonra evlenmeleri durumunda ise çocuk velâyeti anne ve babaya ait olmaktadır. TMK m.336/2'ye göre ortak hayata son verilmiş veya ayrılık hâli gerçekleşmişse hâkim, velâyeti eşlerden birine verir şeklindedir düzenlenmiştir. Fakat, 6684 sayılı Kanun ile "11 No'lu Protokol ile Değişik Insan Haklarını ve Ana Hürriyetleri Korumaya Dair Sözleşme'ye Ek 7 No'lu Protokol"ün yürürlüğe girmesi ile çocuğun menfaatine uygun olduğu durumlarda, ortak velâyet kararı verilebilir. Anne ve babanın anlaşamadıkları için, velâyet hakkından yoksun bırakılmaları çok büyük bir eksikliktir. Bu nedenle, ortak velâyet kararının imkânlı olması, çocuğun yüksek yararı ilkesi gereği önemli bir adımdır.

Rus Hukukuna göre, velâyet: anne ve baba gözetimi dışında kalan on dört yaşını doldurmamış çocukların, yetimlerin ve ehliyetsizlerin yetiştirilmesi, eğitilmesi, mülkiyet hakları ile gayri mülkiyet haklarının ve menfaatlerinin korunmasıdır. Türk Hukukunda velâyetle ilgili kararları aile

289 Serozan, s.251; Görgeç, s.29; Zeybek, s.9; Özer Taşkın, s.35; Çetinkaya s.12-13;

Karaca, s.8; Dural/ Öğüz / Gümüş, s.352.

290 Войтович, s.142; Рузакова, s.149; Попова, s.61. 
mahkemesi verir. Rus Hukukunda ise velâyete ilişkin tüm kararları Velâyet ve Vesayet Kurumu verir. Velâyet ve Vesayet Kurumunun kararını kabul etmeyen taraf mahkemeye itiraz edebilir. Türk Hukukunda da aile işlerine bakan mahkemeden ayrı olarak, kendiliğinden denetleme yetkisine sahip böyle bir sisteme yer verilmesi gerekir. Aile mahkemesi, boşanma, nafaka ve bunun gibi birçok konuda görev yaptığı için, velâyetle ilgili işlemlere yeterli özeni gösteremeyebilir veya velâyeti sürekli kontrol edemeyebilir. Daha önce de belirtildiği gibi, sağlıklı toplumun temeli çocuk ve çocuğun aile ile ilişkisidir. Günlük hayatta anne ve babası boşanmış çocukların, velâyet kendisine bırakılan taraflarla mutsuz yaşadığı ve kişisel gelişimlerinin engellendiği basımdan ve gazetelerden görülebilir. Bu nedenle, velâyet kendisine bırakılan tarafın maddî durumu ve yaşadığı alanın incelenmesi, velâyet altındaki çocuğun memnuniyeti ve psikolojik durumunun devamlı kontrol edilebilmesi için böyle bir kurum şarttır. 


\section{TÜRKÇE KAYNAKLAR ${ }^{* * *}$}

Akıncı, Ziya/ Demir Gökyayla, Cemile: Milletlerarası Aile Hukuku, İstanbul 2010.

Akıntürk, Turgut/ Ateş Karaman, Derya: Aile Hukuku, 6098 Sayılı Yeni Borçlar Kanununa Uyarlanmış, C.2, 15.Baskı, İstanbul 2013 (Akıntürk/Ateş Karaman, Aile).

Akıntürk, Turgut/ Ateş Karaman, Derya: Medeni Hukuk, 6098 Sayılı Yeni Borçlar Kanununa Uyarlanmış, 19.Baskıdan Tıpkı 27.Baskı, İstanbul 2013 (Akıntürk/Ateş Karaman, Medeni).

Akkurt, Sinan Sami: Çocuğun Kişiliğinin Korunması ve Velâyetin Belirlenmesinde Çocuğun Menfaati Olgusu, Prof. Dr. Rona Serozan'a Armağan, C.1, İstanbul 2010, s. 91-120 (Akkurt, Makale).

Akkurt, Sinan Sami: Türk Medenî Hukukunda Evlenmenin Butlanı, Konya 2015 (Akkurt, Kitap).

Akyüz, Emine: Çocuk Hukuku, Çocukların Hakları ve Korunması, 5.Baskı, Ankara 2016.

Arat, Ayşe: Medenî Kanun'da Velâyetin Kaldırılması Tedbiri ve Bu Tedbirin Uygulanması, MÜHFD, C.2, S.2, Aralık 2012, 275-296.

Arpacı, Abdülkadir: Gerekçeleri ve En Son Değişiklikleri ile Yeni Türk Medeni Kanunu, İstanbul 2008.

Belgin, Derya: Anayasa'nın 90. Maddesinde (7 Mayıs 2004) Yapılan Değişikliğin Getirdiği Sorunlar ve Çözüm Önerileri, ABD, S.4, 2008, 110-113.

Birinci Uzun, Tuba: Türk Medenî Kanunu'na Göre Velâyetin Kullanılması ve Çocuğun Yüksek (Üstün) Yararı Illkesi Doğrultusunda Boşanmada ve Evlilik Dışı Ilişskide Birlikte Velâyet Modeli, Hacettepe HFD, 6(1) 2016, 135-166.

Bozkurt, İkbal: Velinin Velâyetten Doğan Hak Görev Ve Yetkileri, YL Tezi, İstanbul Üniversitesi, Istanbul 2010 https://tez.yok.gov.tr/UlusalTezMerkezi/ (Erişim tarihi: 7.09.18).

Çelik, Cemil: Velâyetin Kaldırıması, AÜHFD, C.54, S.1, 2005.

*** Aynı yazarın farklı eserlerine yapılan atıfları ayırmak için kullanılan kısaltmalar, ilgili eserin sonunda parantez içinde verilmiştir. 
Çetinkaya, Volkan: Insan Hakları Hukuku Açısından Velâyet Hakkı, YL Tezi, Marmara Üniversitesi, İstanbul 2009 https://tez.yok.gov.tr/UlusalTezMerkezi/ (Erişim tarihi: 7.09.18).

Doğan, İzet: Öğretide ve Uygulamada Milletlerarası Aile Hukuku ve Milletlerarası Usul Hukuku, Ankara 2010.

Dural, Mustafa/ Öğüz, Tufan/ Gümüş, Mustafa Alper: Türk Özel Hukuku, Aile Hukuku, C.3, 13.Baskı, İstanbul 2018.

Elçin, Evgen Gülçin: Türk Medeni Kanunu'nda Soybağı ve Çocuğun Korunmasında Revize Edilmesi Gereken Hükümler, MHB, Yıl 35, S.1, 2015.

Gençcan, Ömer Uğur: 4721 Sayılı Türk Medeni Kanunu Yorumu, Ankara 2015.

Gökçe, Ümit: Medeni Hukuk, Prestij Kitapları III, Ankara 2004.

Görgeç, Başak: Türk Medeni Kanunu'nda Velâyet Hükümleri ve Özellikle Çocuğun Korunması, YL Tezi, Marmara Üniversitesi, İstanbul 2011 https://tez.yok.gov.tr/UlusalTezMerkezi/ (Erişim tarihi: 7.09.18).

Grassınger, Gülçin Elçin: Türk Medeni Kanununda Yer Alan Velâyet Hükümleri Kapsamında Küçüğün Kişi Varlığının Korunması İçin Alınacak Tedbirler, 1. Baskı, İstanbul 2009.

Hatemi, Hüseyin/ Kalkan Oğuztürk, Burcu: Aile Hukuku, 4.Bası, İstanbul 2004.

Helvacı, Serap/ Erlüle, Fulya: Medeni Hukuk, İstanbul 2011.

Karaca, Hilal: Türk Hukukunda Velâyetin Kapsamı ve Hükümleri, YL Tezi, İstanbul Ticaret Üniversitesi, İstanbul 2014 https://tez.yok.gov.tr/UlusalTezMerkezi/ (Erişim tarihi: 7.09.18).

Karakayalı, Gökhan: Velâyet Hakkının Kullanımasına Iliş̧kin Hukukî Sorunlar Ve Özellikle Koruyucu Aile Uygulaması, YL Tezi, İstanbul Üniversitesi, İstanbul 2009 https://tez.yok.gov.tr/UlusalTezMerkezi/ (Erişim tarihi: 7.09.18).

Kılıçoğlu, Ahmet: Medenî Hukuk, Temel Bilgiler, 3. Bası, Ankara 2013 (Kılıçoğlu, Medenî).

Kılıçoğlu, Ahmet: Medenî Kanun'umuzun Aile - Miras - Eşya Hukukuna Getirdiği Yenilikler, 2.Bası, Ankara 2004 (Kılıçoğlu, Yenilikler).

Oy, Osman: Boşanmanın Hukukî Neticeleri, Nafaka-Tazminat- Velâyet -Mal Paylaşımı ve Aile konutu, İstanbul 2008. 
Özer Taşkın, Özden: Velâyette Çocuğun Yüksek Yararı İlkesi, YL Tezi, Anadolu Üniversitesi, Eskişehir 2006 https://tez.yok.gov.tr/UlusalTezMerkezi/ (Erişim tarihi: 7.09.18).

Öztan, Bilge: Medeni Hukuk'un Temel Kavramları, Ankara 2014.

Öztekin Gelgel, Günseli: Devletler Özel Hukukunda Velâyet, Çocuk Kaçırmaları, Evlat Edinmeye iliş̧in Problemler, İstanbul Ticaret Üniversitesi Sosyal Bilimler Dergisi Yıl:4 S.8 Güz 2005/2 s.119-148.

Öztürk, Mehmet Atıf: Velâyetin kaldırılması, YL Tezi, Akdeniz Üniversitesi, Antalya 2009 https://tez.yok.gov.tr/UlusalTezMerkezi/ (Erişim tarihi: 7.09.18).

Öztürkmen İcan, Yeşim: Hâkimin Takdir Yetkisinin Velâyete illişkin Yargıtay Karar Örnekleri Üzerinde Değerlendirilmesi, YL Tezi, Ondokuz Mayıs Üniversitesi, Samsun 2015 https://tez.yok.gov.tr/UlusalTezMerkezi/ (Erişim tarihi: 7.09.18).

Partalcı, Rumeysa: Yabancı Devletlerden Alınan Velâyet Kararlarının Tenfizi, YL Tezi, İstanbul Üniversitesi, İstanbul 2014 https://tez.yok.gov.tr/UlusalTezMerkezi/ (Erişim tarihi: 7.09.18).

Polat, Oğuz/ Güldoğan, Evin: Uzman Görüşünün Boşanma Davalarında Velâyetin Saptanmasındaki Önemi, TBB Dergisi 2015 (118).

Ruhi, Ahmet Cemal: Boşanma ile illgili Mahkeme Ilamlarının Türkiye'de Tanınması ve Tenfizi, Ankara 2003.

Serdar, Ilknur: Birlikte Velâyet, DEÜHFD, C.10, S.1 2008, s. 155-197.

Serozan, Rona: Çocuk Hukuku, 2. Baskı, İstanbul 2017.

Şener, Esat: Vesayet ve Velâyet Hukuku, Ankara 1996.

Tutumlu, Mehmet Akif: Teorik ve Pratik Boşanma Yargılama Hukuku, C.2, 2. Baskı, Ankara 2009.

Uyumaz, Alper/ Erdoğan, Kemal: Aile Hukukundan Doğan Uyuşmazlıkların Alternatif Çözüm Yolları, DEÜHFD, C.17, S.1, 2015, s.119-169.

Uyumaz, Alper: Eski ve Yeni Medeni Kanun Açısından Boşanmanın Kişisel Sonuçları, MÜHFD, 10. Yıl Kuruluş Armağan, 2008/2, s.271-300 (Uyumaz, Boşanma).

Uyumaz, Alper: Türk Medeni Kanununa Göre Çocuğun İhmâli ve Anne Babaya Karşı Korunması, Legal Hukuk Dergisi, C.14, S.160, 2016, s.1973-2005 (Uyumaz, Çocuğun Korunması).

Yavuz, Cevdet: Türk Medeni Kanunu, 11. Baskı, İstanbul 2014. 
Zevkliler, Aydın/ Havutçu, Ayşe: Yeni Medeni Kanuna Göre Medeni Hukuk (Temel Bilgiler), 2. Baskı, Ankara 2002.

Zeybek, Elvan: Velâyet Hakkının Kullanımı, YL Tezi, Gazi Üniversitesi, Ankara 2009 https://tez.yok.gov.tr/UlusalTezMerkezi/ (Erişim tarihi: 7.09.18).

Zeytin, Zafer/ Ergün, Örner: Türk Medeni Kanunu, 2. Baskı, Ankara 2013.

\section{RUSÇA KAYNAKLAR}

Войтович Е.П.: Семейное Право, Учебное Пособие, Новосибирск 2014.

Гомола А.И. / Гомола И.А.: Семейное право, Учебник, Москва 2014.

Крашеников П.В.: Семейное Право, Учебник, г.Москва 2008.

Кузнецова Е.М.: Организация Опеки и Попичительства Над Несовершеннолетними На Муниципальном Уровне, УдК 352, 364, г.Омск 2010.

Максимов И.Н.: Опека и Попичителство Как Вид Социальной Заботы Государства, Издание Наука Вестник, г.Шадринск 2013.

Мартынова Е.В.: Опека и Попичетелство, Учебное Пособие, г.Ростов На Дону 2014.

Низамиева О.Н.: Семейное Право, учебно-методический комплекс дисциплины, Казанский (Приволжский) федеральный университет, Казань 2014.

Попова Т.А.: Проблемы Правового Регулирования Отношений, Связанных С Установлением Над Несовершеннолетним (Опеки и Попечительства), Выпускная Квалификационная Работа, Томский Государственный Университет, г.Томск 2016.

Пулатов Т.А.: Правовое регулирование опеки и попечительства в Российской Федерации, Магистерская Диссертация, Тольяттинский государственный университет, г.Тольятти 2017. https://dspace.tltsu.ru/handle/123456789/3239 (Erişim tarihi: 5.01.2018)

Рузакова О.А.: Семейное Право, Учебник, г.Москва 2010.

Сумбаа Ш.А.: Опека и попечительство как форма социальной защиты детей, оставшихся без попечения родителей, Выпускная 
Квалификационная Работа, Кызылский Педагогический Институт, Кызыл 2015. 


\section{KISALTMALAR}

$A B$.

: Avrupa Birliği

$A B D$.

: Ankara Barosu Dergisi

AÜHFD.

: Ankara Üniversitesi Hukuk Fakültesi Dergisi

AY.

: Türkiye Cumhuriyeti 1982 Anayasası

b.

: Bent

Bkz.

: Bakınız

BMÇHDS. : Birleşik Milletler Çocuk Haklarına Dair Sözleşme Bülteni

C.

: Cilt

DEÜHFD. : : Dokuz Eylül Üniversitesi Hukuk Fakültesi Dergisi

E.

: Esas

EMK.

: 743 Sayılı Eski Türk Medenî Kanunu

f.

: Fikra

HD.

: Hukuk Dairesi

HFD.

: Hukuk Fakültesi Dergisi

HMK.

: 6100 Sayılı Hukuk Muhakemeleri Kanunu

HUAK.

: 6325 Sayılı Hukuk Uyuşmazlıklarında Arabuluculuk Kanunu

$\mathrm{K}$.

: Karar

m.

: Madde

$\mathrm{MHB}$.

: Milletlerarası Hukuk ve Milletlerarası Özel Hukuk

RA.

: 12.12.1993 tarihinde kabul edilen Rus Anayasası

RAK.

: N 223-Ф3 Sayılı Rus Aile Kanunu

REK.

: N 273-Ф3 Sayılı Rus Eğitim Kanunu

RF.

: Rusya Federasyonu

RG.

: Resmi Gazete

RMK.

: Rus Medeni Kanunu

RVVFK.

: N 48-\$3 Sayllı Rus Velâyet ve Vesayet Federal Kanunu

$\begin{array}{ll}\text { S. } & \text { :Sayfa } \\ \text { S. } & \text { :Sayı }\end{array}$

TBK.

: 6098 Sayılı Türk Borçlar Kanunu

TC.

: Türkiye Cumhuriyeti 
TMK.

: 4721 Sayılı Türk Medeni Kanunu

$\mathrm{vb}$.

: ve benzeri

Y.

: Yargitay

$\mathrm{YL}$.

: Yüksek Lisans 